IZA DP No. 9173

The Effects of the Earned Income Tax Credit on Children's Health, Quality of Home Environment, and Non-Cognitive Skills

Susan Averett

Yang Wang

July 2015 


\title{
The Effects of the Earned Income Tax Credit on Children's Health, Quality of Home Environment, and Non-Cognitive Skills
}

\author{
Susan Averett \\ Lafayette College \\ and IZA \\ Yang Wang \\ Lafayette College
}

Discussion Paper No. 9173

July 2015

IZA

P.O. Box 7240

53072 Bonn

Germany

Phone: +49-228-3894-0

Fax: +49-228-3894-180

E-mail: iza@iza.org

Any opinions expressed here are those of the author(s) and not those of IZA. Research published in this series may include views on policy, but the institute itself takes no institutional policy positions. The IZA research network is committed to the IZA Guiding Principles of Research Integrity.

The Institute for the Study of Labor (IZA) in Bonn is a local and virtual international research center and a place of communication between science, politics and business. IZA is an independent nonprofit organization supported by Deutsche Post Foundation. The center is associated with the University of Bonn and offers a stimulating research environment through its international network, workshops and conferences, data service, project support, research visits and doctoral program. IZA engages in (i) original and internationally competitive research in all fields of labor economics, (ii) development of policy concepts, and (iii) dissemination of research results and concepts to the interested public.

IZA Discussion Papers often represent preliminary work and are circulated to encourage discussion. Citation of such a paper should account for its provisional character. A revised version may be available directly from the author. 


\section{ABSTRACT}

\section{The Effects of the Earned Income Tax Credit on Children's Health, Quality of Home Environment, and Non-Cognitive Skills*}

In 1993, the benefit levels of the Earned Income Tax Credit (EITC) were changed significantly based on the number of children in the household. Employing a difference-indifferences plus mother fixed-effects framework, we find better mother-rated health for children of unmarried black mothers and married white and Hispanic mothers, lower accident rates for children of married white and Hispanic mothers, and improved home environment quality for children of unmarried white and Hispanic mothers. Our results provide new evidence of the effects of the 1993 EITC expansion and therefore have important policy implications.

JEL Classification: $\quad 112,138, \mathrm{~J} 13$

Keywords: $\quad$ EITC, child health, home environment, non-cognitive skills

Corresponding author:

Susan Averett

Lafayette College

Department of Economics

Easton, PA 18042

USA

E-mail: averetts@lafayette.edu

\footnotetext{
* We have benefited greatly from helpful comments from Nicholas Stacy, Dhaval Dave, David Simon, and participants at the 2013 Eastern Economic Association Annual meeting, the 2013 Southern Economic Association Annual meeting, and the 2014 American Economic Association Annual meeting. All remaining errors are our own.
} 


\section{Introduction and Review of Previous Literature}

In 2013, 14.5 percent of Americans had incomes below the poverty level and approximately one in five children lived in poverty (Census Bureau, 2014). Although the child poverty rate in the U.S. has recently been falling, it remains stubbornly greater than that of nearly all other OECD countries (OECD, 2009). For decades, a vigorous national debate has existed over how to best improve the lives of the poor, particularly children. In the aftermath of the 1996 welfare reform, government spending on traditional welfare programs has slowed and the Earned Income Tax Credit (EITC) has become the nation's largest anti-poverty program in terms of dollars spent. ${ }^{1}$ Scholars have exerted a considerable amount of effort to ascertain the effect of the EITC on poverty reduction (Scholz, 1994; Neumark and Wascher, 2001; Meyer, 2010), labor force participation (Eissa and Leibman, 1996; Meyer and Rosenbaum, 2001; Hotz and Scholz, 2003; Cancian and Levinson, 2006; Eissa et al., 2008), educational attainment (Miller and Zhang, 2009), and marriage (Ellwood, 2000; Dickert-Conlin, 2002). In this paper, we focus on the potential effects of the EITC on three outcomes that have been linked to later life well-being and economic success: children's health, the quality of their home environment, and their non-cognitive skills.

Economists have been interested in whether certain welfare reform has led to better health behaviors/outcomes for recipients and their children (e.g., Bitler et al., 2005; Dunifon et al., 2006; Corman et al., 2013), because health is an important consumption and investment good (Grossman, 1972) and children's health is particularly crucial for the accumulation of human capital and hence their future health and socioeconomic status (e.g., Currie, 2005; Currie and Stabile, 2006; Heckman, 2007). However, only a few studies have examined the effect of the EITC on the health and/or health behaviors of adult recipients ${ }^{2}$, and even fewer studies have examined how the increased income

\footnotetext{
${ }^{1}$ Information on spending was obtained from the Tax Policy Center at: http://www.taxpolicycenter.org/taxfacts/displayafact.cfm?Docid=266, accessed 9/18/2014.

${ }^{2}$ For example, Schmeiser (2009), using the same dataset as we do in this paper and an Instrumental Variable method, finds that an increase in family income due to the generosity of state and federal EITC benefits significantly raised the Body Mass Index (BMI) and the probability of being obese for
} 
from the EITC might affect children's health. For example, Baker (2008) and Hoynes et al. (2012), using different datasets but similar identification and estimation methods, find that an EITC-induced increase in family income is associated with a 7 to 14 gram increase in average birthweight and a 6.7 to $10.8 \%$ reduction in low birthweight rate, respectively. In related work, Strully et al. (2010) exploit state-level EITC variation and find evidence that the EITC reduces the incidence of low birthweight using census data. Finally, Baughman (2012) examines the effects of the state-level EITC on a wider array of children's health related outcomes including mother-rated health and insurance coverage and finds that states which adopted the EITC saw higher rates of private health insurance coverage and lower rates of public health insurance coverage for children.

If we say that we still know little about how the EITC affects children's health, then we can say that we know almost nothing about its effects on another two important measures of children's outcomes: their home environment quality and their non-cognitive skills. ${ }^{3}$ Home environment quality has been linked to health outcomes including asthma and obesity (Crawford et al., 2010; Ege et al., 2011; Carneiro et al., 2013). And it is also an important predictor of children's cognitive ability, school readiness and hence later life success (Todd and Wolpin, 2007; Carneiro et al., 2013).

Similarly, a growing body of evidence has documented that non-cognitive skills, defined as personality, social, and emotional traits, are important predictors of school readiness (Duncan et al., 2007) and later life economic success as they are crucial components of human capital (Heckman et al., 2005; Cunha et al. 2010; Cunha and Heckwomen with EITC-eligible earnings. Averett and Wang (2012) and Cowan and Tefft (2012) examine the effect of the 1993 EITC expansion on women's smoking behavior. Though using different datasets and focusing on different groups of women, both studies find that the increase in income following the EITC expansion led to a significant decline in the likelihood of smoking for (certain groups of) women. Evans and Garthwaite (2014) examine the effects of the 1993 EITC expansion on female recipients' health using data from the Behavioral Risk Factor Surveillance Survey (BRFSS) and the National Health Interview Survey (NHIS), and find that the number of days with poor mental health and the fraction reporting excellent or very good health improved and risky levels of biomarkers fell for mothers of two or more children relative to the mothers with only one child.

${ }^{3}$ Related work by Dahl and Lochner (2012) examines the effect of the EITC expansion on children's cognitive outcomes. Children's scores on tests of cognitive ability have long been found to be predictive of later life outcomes (Todd and Wolpin, 2007; Cunha et al., 2010; Cunha and Heckman, 2010) and Dahl and Lochner show that a $\$ 1,000$ increase in family income could raise math and reading test scores by $6 \%$ of a standard deviation in the short run, and this gain is even larger for children from disadvantaged families. 
man, 2010). Both the quality of the home environment and non-cognitive skills are also important components/predictors of the racial gap in school readiness and cognitive ability. For example, Currie (2005) calculates that racial differences in health conditions and in maternal health and behaviors together may account for as much as a quarter of the racial gap in school readiness, and Todd and Wolpin (2007) note that equalizing home inputs at the average levels of white children would close the black-white and the Hispanic-white test score gaps in math and reading by about $10-20 \%$.

In this paper, we aim to fill this gap in the literature by focusing on the potential health, quality of home environment, and non-cognitive skills effects on the children of the recipients of the 1993 EITC expansion, the largest expansion to-date of the EITC. Specifically, in 1993, then President Bill Clinton expanded the EITC as a strategy to support minimum wage workers, famously stating "No one should have to work forty hours a week and raise a family in poverty." (Klein, 2003, p.55) This expansion dramatically increased the difference in EITC benefits between eligible families with two or more children and those with only one child. We are therefore able to exploit the differential trends in children's health, quality of home environment, and non-cognitive skills after this policy change between children in a family with two or more EITC-eligible children and those in a family with only one EITC-eligible child, to examine the effect of the EITC, the largest anti-poverty program in the United States, on children's outcomes of interest.

There are three channels through which the EITC expansion could influence children's outcomes that we study in this research. First, there is a direct income effect. The 1993 EITC expansion was the largest expansion in EITC history. It increased income for its recipients through increased EITC benefit levels, and this increased family income may impact children's outcomes. For example, the existence of a positive income/health gradient is well-known and has been documented for a wide array of health outcomes and health-related behaviors (e.g., Deaton, 2002; Adda et al., 2009). Increased income may allow the family to purchase higher-quality food and better medical care, and improve the quality of their housing/home environment thus improving child health. 
Previous research has found that poverty is associated with increased exposure to lead paint, increased child mortality and an increased likelihood of hospitalization (Duncan and Brooks-Gunn, 2000), though whether family income has a causal effect on children's health remains an important economic question (e.g., Case et al., 2002; Currie and Stabile, 2003; Currie, 2009).

Second, expanding the EITC might influence children's outcomes through its effect on mother's labor supply. The EITC was designed to and has been found to encourage labor force participation in the low-income population because of its negative income tax structure. ${ }^{4}$ The effect of this increased labor supply on children's outcomes can be complex (Gordon et al., 2007; Gennetian et al., 2010; Morrill, 2011). On the one hand, when low-income parents work more, they are more likely to earn higher income and higher income could lead to a positive change in children's outcomes, as discussed above. On the other hand, however, increased maternal employment may also decrease mothers' ability to care for and supervise their children, leading perhaps to less healthful activities, such as eating poorly or engaging in a more sedentary lifestyle. Increased maternal employment could also lead to more non-parental child care, and this may have its own effects on children. For example, non-parental child care has been associated with an increase in childhood communicable diseases (Bradley, 2003) and an increase in childhood obesity (Maher, 2008).

Third, expanding the EITC may impact children's outcomes through changed health and/or health behaviors of the parents. As discussed above, the EITC has been found to be largely beneficial for mothers' health, mentally and physically (Evans and Garthwaite,

\footnotetext{
${ }^{4}$ There is a considerable literature on the effect of the EITC on labor supply and scholars have examined both the intensive (hours or weeks worked) and the extensive (labor force participation) margins. From a purely theoretical perspective, economic theory indicates that the EITC expansion should unambiguously increase the labor force participation of unmarried women. The effect of the EITC on the labor force participation decision of married women is more complex as it depends also upon their husbands' labor supply. At the intensive margin, the effect of the EITC expansion depends on where on the subsidy range the individual is located. The three distinct credit regions of the federal EITC program, the phase-in, the plateau and the phase-out regions, each yield their own labor supply incentives for workers already in the labor force. Previous research has found that the EITC expansions that occurred in the 1990s tended to increase labor force participation but had little effect on hours worked (Eissa and Liebman, 1996; Eissa and Hoynes, 2006) though some studies find no effect of EITC expansion on either margin (e.g. Cancian and Levinson, 2006).
} 
2014), and a healthy mother can take better care of her children and pay more attention to their health, the quality of their home environment, and their non-cognitive skills. In addition, there has been research showing that the EITC leads mothers to smoke less (Averett and Wang, 2012 and Cowan and Tefft, 2012), which is good for children through less exposure to second-hand smoke and/or a positive role-model effect.

Because expanding the EITC might impact children in different directions through these three channels, the direction of the final/composite effects is an empirical question depending on the relative sizes of the various effects discussed above. Using a differencein-differences plus mother fixed-effects (DD+FE) method, we find that the 1993 EITC expansion statistically significantly improved mother-rated health for children of unmarried black mothers and married white and Hispanic mothers, lowered the probabilities of having accidents for children of married white and Hispanic mothers, and improved home environment quality for children of unmarried white and Hispanic mothers. Our results provide new evidence on the positive effects of the 1993 EITC expansion on children's health and the quality of their home environment, and therefore have important policy implications.

Our research makes the following contributions. First, it is among the first to examine, at the individual level, the effects of the EITC expansion on children's health, the quality of their home environment, and their non-cognitive skills, and therefore contributes to a growing literature on the potential spillover effects of non-health safety net programs (e.g. Dunifon et al., 2006; Leonard and Mas, 2008; Strully et al., 2010; Baughman 2012; Hoynes et al., 2012). As a major anti-poverty program in the United States, it is important to include a full range of benefits in any cost-benefit analysis of the EITC, especially given that the United States continues to struggle with ways to improve the health and decrease the health care costs of its population. More importantly, because interventions in childhood may have disproportionately large returns in terms of human capital accumulation and adult socio-economic status, it is particularly important to focus on effects of various public policies on children. Focusing on the EITC-eligible population is also important since children from low income families tend 
to have worse health status, poorer home environments and lower non-cognitive skills that may compromise their future labor market success (Currie, 2009).

Second, our paper uses a longitudinal dataset, which makes it possible to employ a difference-in-differences plus mother fixed-effects estimation method. Our estimates are therefore free of family-level time-invariant unobserved heterogeneity, which cannot be easily achieved by using (pooled) cross sectional data or even panel data at more aggregate levels. Most studies on the health effects of the EITC instead use repeated cross sectional data sets such as the Behavioral Risk Factor Surveillance System, the National Health Interview Survey, the Current Population Survey, or Vital Statistics (e.g., Evans and Garthwaite, 2014). It is important to show and indeed encouraging to the EITC literature that results on the positive effects of the EITC on children's health and their home environment are robust to the inclusion of mother fixed effects. Longitudinal data also allow us to explore the dynamics of the effects of the EITC and see how these effects on our outcome variables change over time relative to the policy change, which is particularly important since the EITC policy does not "turn off" (as long as parents remain eligible) and therefore may have accumulating effects throughout children's childhood.

The rest of this paper proceeds as follows. In the second section, we present details of the EITC with a focus on the 1993 expansion. Following that we discuss our data and econometric models and then our empirical results. We offer concluding comments in the final section.

\section{The Earned Income Tax Credit and the Omnibus Reconciliation Act of 1993}

The EITC is a refundable tax credit that provides cash payments to qualifying families. First started in 1975 as a rather modest tax credit for the working poor designed to offset social security taxes and to encourage the poor to work, the EITC has grown into one of the nation's largest anti-poverty programs in terms of the amount of money the federal 
government transfers to low income individuals who qualify for the credit and is one of the main federal policy tools for redistributing income. By 1996, spending on the EITC was almost double the spending on the Aid to Families with Dependent Children (AFDC) program, which until the early 1990s was the primary source of spending for the poor, ${ }^{5}$ and in 2011 over 28 million people received nearly $\$ 65$ billion in EITC benefits. ${ }^{6}$ The EITC generally enjoys bipartisan support because it reduces poverty while rewarding work, and some economists argue that the EITC works better than the minimum wage at improving the wellbeing of the working poor due to its targeted nature (e.g., Burkhauser et al., 1996; Neumark and Wascher, 2001).

For qualifying (low income) households, the EITC provides cash transfers as a percentage of earned income and these transfers increase with household income. The EITC benefit schedule is divided into three phases defined by income levels. For those with the lowest incomes, the percentage benefit is the greatest. Once the maximum benefit is reached, the benefits received by recipients remain constant over a range of income. The third phase begins once a certain amount of earned income is reached and the benefits start to decrease with income. Finally, over a certain threshold, the EITC benefits are completely phased out. Different income cutoff points and rates of increase/decrease in benefits affect how generous the EITC is to low income families and individuals.

The EITC policy has undergone several changes over time. The focus of this paper is on the impact on children's health, the quality of their home environment, and their non-cognitive skills of the 1993 Omnibus Reconciliation Act (OBRA93), signed by then President Clinton which dramatically increased the difference in benefits between families with two or more children and those with only one child. The difference was first created as part of the Omnibus Reconciliation Act of 1990, but on a much smaller scale. Because of this policy change, the maximum benefits for families with two or more children more than doubled and for the first time a meaningful separation was created

\footnotetext{
${ }^{5}$ http://www.taxpolicycenter.org/taxfacts/displayafact.cfm?Docid=266, accessed 05/05/2014.

${ }^{6}$ http://taxpolicycenter.org/taxfacts/displayafact.cfm?Docid=37, accessed 05/01/2014.
} 
for eligible families based on the number of children as reported in Table $1 .^{7}$

The credit has three parameters that policymakers can manipulate: the credit rate (Table 1, column 1), the maximum amount of the credit (column 2) and the phase out rate/range (columns 3, 4 and 5). As is clear from Table 1, back in 1991, the difference in maximum benefits between families with one child and families with two or more children was less than $\$ 40$. In 1996 , however, this difference jumped to over $\$ 1,400$. This general structure is still in place today. ${ }^{8}$ Because of this exogenous policy change, we are able to provide empirical evidence on the effects of the EITC expansion on our outcomes of interest for recipients' children.

Note that although Dahl and Lochner (2012) report that the 1993 expansion increased eligible families' incomes by as much as $20 \%$, the typical family might not receive the full EITC benefit. Indeed, research has shown that the average difference in EITC benefits between mothers with one versus those with two or more children is $\$ 480$ (Hotz and Scholz, 2006). While the magnitude of this difference in income may appear small in absolute terms, whether it could be a relatively large income shock for the wellbeing of the children with low-educated mothers with two or more children under the age of 19 in the household is an empirical question.

\section{Data}

We use data from the 1979 National Longitudinal Survey of Youth (NLSY79) and the NLSY79 Child and Young Adult (NLSCYA) to examine the effects of the 1993 EITC expansion on the well-being of the children of low income mothers. The NLSY79 sampled 12,686 individuals who were between the ages of 14 and 21 in 1979 and has followed them ever since, with annual interviews until 1994 and interviews every other year following that through 2010. The NLSCYA cohort is a longitudinal project that follows

\footnotetext{
${ }^{7}$ Tax Policy Center http://www.taxpolicycenter.org/taxfacts/displayafact.cfm?Docid=36, accessed 05/01/2014. The most recent EITC expansion was in 2009 as a part of American Recovery and Reinvestment Act.

${ }^{8}$ See 1040 instruction for the difference in maximum benefits for tax year 2010, http://www.irs.gov/pub/irs-pdf/i1040gi.pdf (accessed 05/01/2014).
} 
the biological children of the women in the NLSY79. ${ }^{9}$ We match the children from the NLSCYA with their biological mothers in the NLSY79 to obtain information on whether the mothers are EITC-eligible and whether they are likely to be affected by the 1993 EITC expansion.

The NLSY79 is the only dataset of which we are aware that allows us to examine the 1993 EITC expansion using children of women who were in their childbearing years at that time and for whom we have longitudinal information — i.e., we can observe the same mothers before and after the expansion and therefore purge our estimates of any family-level time-invariant heterogeneity by the use of mother fixed-effects estimation - an important feature of these data that we exploit in the analyses that follow and is absent in (repeated) cross sectional data. The NLSY79 also oversamples civilian blacks, Hispanics, and the economically disadvantaged non-black/non-Hispanic population, which likely expands our pool of children of EITC-eligible mothers. In addition, the NLSY79 household roster makes it possible to more accurately measure the number of EITC-eligible children (under 19 years of age and living in the household).

We focus on the changes in our outcome variables between 1990, three years before the 1993 EITC expansion, and 1998, three years after EITC-eligible families with two or more children first received their dramatically increased EITC payments due to the policy change. This eight-year period covers four waves of the data: 1990, 1992, 1996, and 1998. We exclude the data from 1994 because 1994 is right in the middle of the policy change. This relatively long time period allows us to analyze the dynamic effect of the EITC expansion on children over time relative to the policy change, which is particularly important since as long as parents remain eligible children will be continuously influenced by this policy change throughout their childhood.

A key question within our research framework is how to restrict the sample to include people likely to be eligible for the EITC. Although the EITC is income-based, previous literature indicates that there are important labor supply consequences of the program

\footnotetext{
${ }^{9}$ See http://www.bls.gov/nls/handbook/2005/nlshc3.pdf for a description of the NLSY79 (accessed 05/01/2014) and http://www.nlsinfo.org/content/cohorts/NLSY79-Children for a description of the NLSCYA cohort (accessed 05/01/2014).
} 
(see Section 1 for citations). Thus, an income-based criterion is inappropriate as this would select the sample based on an outcome and potentially contaminate our results due to sample selection bias.

We employ the same strategy used in the literature (e.g., Averett and Wang, 2012 and Evans and Garthwaite, 2014) and use education to determine who in our sample is likely to be eligible for the EITC. In particular, we regard those mothers with fewer than 13 years of education as potentially eligible for EITC and those with 13 or more years of education as likely ineligible for the EITC. In our sample, we observe that several women obtained more years of education after the policy change, which gave them more than 12 years of education and thus made them very unlikely to be eligible for EITC benefits. We therefore exclude children of those women in our sample to avoid contamination of the estimation results. ${ }^{10}$ There are also some women in our data who switched treatment status after the policy change; i.e., they went from having one EITCeligible child (control group) before 1993 to having two or more EITC-eligible children (treatment group) after 1995 or vice versa. ${ }^{11}$ We exclude children of these women from our sample for the same reason. We also exclude those few observations with missing information on important control variables.

We use the following outcome variables. First, for children's health, we use: (1) illness in the past year, a binary variable generated from the responses to the question, "Has the child had an illness in last 12 mos. requiring medical attention?"; (2) accident in the past year, a binary variable generated from the responses to the question on the "number of accidents or injuries the child has had in the past 12 mos"; and (3) an overall measure of the child's health as rated by the mother ${ }^{12}$.

\footnotetext{
${ }^{10}$ Results from a robustness check where we keep those children whose mothers obtained more than 12 years of education after the policy change and hence may have lost their EITC eligibility are qualitatively the same as our main results and are available upon request.

${ }^{11}$ Results from a robustness check where we keep those children whose mothers switched treatment status after the policy change are qualitatively the same as our main results and are available upon request. In addition, we might worry that the EITC provided incentives for mothers to have more children. However, research indicates that the EITC expansions in 1993 not only did not encourage fertility but led to a small reduction in higher-order fertility among white women (Baughman and Dickert-Conlin, 2009).

${ }^{12}$ This variable is measured on a Likert scale ranging from 1 to 4 with 4 being excellent, 3 being good,
} 
Our measure of the quality of the home environment is the Home Observation Measurement of the Environment (HOME) standardized z-score, ${ }^{13}$ which measures the quality of the home environment provided by a child's family and includes questions regarding the cleanliness of the home, whether the play environment in the home is safe for children, whether regular meals are eaten, whether television time is limited, what type of discipline is used, how often parents read to the child and whether parents assist with homework among other questions. ${ }^{14}$

Finally, our measure of non-cognitive skills is the Behavior Problems Index (BPI) standardized z-score, a 28-item questionnaire administered to parents about their children and a widely used indicator of non-cognitive skills (Cunha et al., 2010). ${ }^{15}$ Higher values of this index indicate more behavior problems and lower non-cognitive skills and it is answered by the mother for children aged four and over. ${ }^{16}$ While there are other health outcomes that we would have liked to include that are available in the NLSYCA such as asthma and ADHD, they were not asked frequently enough for us to use given our research design.

\section{Econometric Models}

As explained in Section 1, we exploit the unique feature of the EITC expansion during 1993 to 1995 to identify the effects of EITC expansion on children's outcomes important

2 being fair, and 1 being poor. This variable was only asked in the years 1992, 1996, and 1998.

${ }^{13} \mathrm{~A}$ general discussion of this measure can be found at: https://www.nlsinfo.org/content/cohorts/nlsy79children/topical-guide/assessments/home-home-observation-measurement, accessed 05/01/2014. A complete list of questions used to construct the HOME scores can be found at https://www.nlsinfo.org/content/cohorts/nlsy79-children/other-documentation/codebooksupplement/appendix-home-sf-scales (accessed 05/01/2014).

${ }^{14}$ Note that although some questions used to construct HOME scores such as cleanliness of the home are at the household level, responses to most questions such as how often parents read to the child and whether parents assist with homework still vary from child to child. Therefore this measure of the quality of home environment is still an individual-level variable.

\footnotetext{
${ }^{15}$ Some researchers focus on "(BPI) Headstrong", a subset of the BPI because they argue it is the best measure of non-cognitive skills (Cunha et al., 2010). When we used this measure our results were qualitatively the same so we only report the overall BPI.
}

${ }^{16}$ Details of this index can be found at: https://www.nlsinfo.org/content/cohorts/nlsy79children/topical-guide/assessments/behavior-problems-index-bpi, last accessed on 06/23/2015. 
for their health, human capital accumulation, and later life success. Our baseline econometric model for the children of EITC-eligible mothers therefore is a straightforward difference-in-differences (DD) framework as follows:

$$
\begin{aligned}
H C_{i j t} & =\beta_{0}+A F T E R_{j t} \beta_{1}+2 K I D S_{j t} \beta_{2}+A F T E R_{j t} 2 K I D S_{j t} \delta_{d d} \\
& +X C_{i j t} \beta_{x c}+X M_{j t} \beta_{x m}+\sum_{m=1}^{50} \text { State }_{m} \lambda_{m}+\varepsilon_{i j t}
\end{aligned}
$$

where $H C_{i t}$ denotes those outcome measures, as described in the Data section, of child $i$ of mother $j$ at time $t$. $\varepsilon_{i j t}$ is the mean-zero idiosyncratic error term. AFTER $R_{j t}$ is a binary variable indicating whether the EITC expansion is effective: if the dependent variable is measured after 1995 , then $A F T E R_{j t}=1$, and 0 otherwise. $2 K I D S_{j t}$ is also a binary variable which equals one if mother $j$ has two or more children at time $t$, and zero otherwise. Because this expansion only affects mothers with two or more children and not those with only one child, $\delta_{d d}$ is the main parameter of interest and captures the effect of the 1993 EITC expansion on the children of EITC-eligible mothers in this framework.

To account for the effects of other explanatory variables on our outcome variables, we also include two sets of covariates $\left(X C_{i j t}\right.$ and $\left.X M_{j t}\right)$ that describe the children and their mothers, respectively, and a set of state dummy variables $\left(\right.$ State $\left._{m}\right) . X C_{i j t}$ includes the child's age and gender, and $X M_{j t}$ includes mother's age, number of children in the household, and mother's years of education. The set of state dummy variables $\left(\right.$ State $\left._{m}\right)$ allows us to control for variation in welfare benefit levels across states, variation in the generosity of public health insurance programs such as Medicaid, as well as different timing in state-level adoption of the EITC (Baughman, 2012). The mid-1990s was a time of great change in welfare programs in the U.S., so these state fixed effects are particularly important. To control for various time-varying differences across states in labor market trends and welfare reforms that may have also affected children but cannot be controlled for using state fixed effects, we further include as covariates in $X M_{j t}$ statelevel unemployment rates (as a measure of labor market trends), and AFDC maximum 
benefits and Medicaid eligibility (income levels relative to poverty lines) for children (as measures of welfare reforms).

As mentioned in Section 1, the data sets we use, NLSY79 and NLSCY, are longitudinal, which allows us to control for time-invariant mother fixed effects as specified in the following expanded DD model:

$$
\begin{aligned}
H C_{i j t} & =\beta_{0}+A F T E R_{j t} \beta_{1}+2 K I D S_{j t} \beta_{2}+\text { AFTER } R_{j t} 2 K I D S_{j t} \delta_{d d} \\
& +X C_{i j t} \beta_{x c}+X M_{j t} \beta_{x m}+\sum_{m=1}^{50} \text { State }_{m} \lambda_{m}+\alpha_{j}+\varepsilon_{i j t}
\end{aligned}
$$

where $\alpha_{j}$ measures the mother fixed effects or unobserved time-invariant heterogeneity between different families. The inclusion of $\alpha_{j}$ is important, because omitted variable bias will likely result if $\alpha_{j}$ is correlated with any of the control variables and yet is excluded from the model.

\section{Results}

Because of well-known differences in our outcome variables across race, we estimate our models separately by race/ethnicity (Currie, 2005; Adler and Rehkopf, 2008; Carneiro et al., 2013). Specifically, we consider two race/ethnicity subsamples: white and Hispanic mothers, and black mothers. ${ }^{17}$

In addition, the literature shows that parents' marital status plays an important role in determining children's health and other outcomes (e.g., McLanahan, 2004; Ribar, 2004; Blackwell, 2010; Bzostek and Beck, 2011), and previous research has also established that the EITC has no impact on low-income women's marital status (Ellwood,

\footnotetext{
${ }^{17}$ In the NLSY79, the only three mutually exclusive categories for race/ethnicity were black, Hispanic, and non-black, non-Hispanic. Because Hispanics may identify as white or black and considering the sample size, we combine white mothers with Hispanic mothers, calling this subsample the white and Hispanic subsample. We then refer to the group of black mothers as the black subsample. In addition, the race/ethnicity of the mothers is identical to that of their children, so we do not differentiate between mothers' and children's race/ethnicity. In robustness checks not reported but available upon request, we conduct our analysis separately for the three race/ethnicity groups, by combining Hispanic mothers with black mothers instead, and by pooling all three race/ethnicity groups together, and the results are largely the same.
} 
2000). We therefore further analyze the effects of the EITC policy change on children's outcomes by their parents' marital status as well. Specifically, we now divide the children in our sample into four groups: two different races/ethnicities and two parental marital statuses: married at the time of interview or not. Table 2 reports sample means for children by their (mothers') race/ethnicity, parental marital status, and treatment status, denoted by the number of EITC-eligible children in the household, for mothers with less than 13 years of education (and therefore more likely to be eligible for the EITC) in our sample.

When we look at the measures of children's outcomes of interest, we see that there are sizable differences in these outcomes across race/ethnicity, marital status, and numbers of EITC-eligible children. For example, children of white and Hispanic mothers were more likely to have an illness needing medical attention or an accident in the past year, as well as higher HOME and lower BPI scores than those of black mothers.

When we turn our attention to the characteristics of the children and their mothers in our sample, we see that children of different groups are of similar age on average, ${ }^{18}$ and about half of them are male. All mothers are of a similar age too, reflecting the cohort nature of the NLSY sampling scheme, and have similar years of education on average which is expected given that all the mothers in our sample have less than 13 years of education. In addition, black mothers have more EITC-eligible children in the household compared to white and Hispanic mothers. Finally, white and Hispanic mothers are more likely to live in a state with higher AFDC benefits and higher unemployment rates.

Before reporting our estimation results, it is instructive to consider what the average family in our sample received in terms of the EITC benefits. Table 3 shows the EITC benefits received by EITC-eligible families in our sample by the numbers of EITC-eligible children in the households for years 1990, 1992, 1996, and 1998. As is clear from the table, in 1990 and 1992, the difference in benefits between these two groups of families was rather small (around $\$ 50$ to $\$ 200$ ); in 1996 and 1998, however, the mean difference

\footnotetext{
${ }^{18}$ In our main specification, we use a continuous measure of children's age. In a robustness check not reported but available upon request, we use dummy variables to control for children's age given how rapidly children develop. Once again, our results are qualitatively the same.
} 
in benefits between families with only one child and those with two or more children rose to $\$ 300$ to $\$ 400$ in our sample. ${ }^{19}$ This is somewhat less than what Hotz and Scholz (2006) report as the average EITC benefit but the difference is likely due in part to the composition of our sample.

Table 4 presents the summary statistics for the five outcome variables by race/ethnicity, parental marital status, and treatment status (1 EITC-eligible child versus 2 or more EITC-eligible children), before and after the policy change. This table previews some of our parametric estimation results. For example, in Table 4 looking at white and Hispanic married women before the policy change we see that 10.0 percent of the children in the treatment group and 8.0 percent in the control group had an accident in the past year. After the policy change, however, these two numbers were 12.0 for the treatment group and 15.0 for the control group, leading to an unadjusted difference-in-differences estimate of $(12.0-15.0)-(10.0-8.0)=-5.0$ percentage point. This indicates that although accident rates were overall trending upwards during this time period, without controlling for any control variables or mother fixed effects, the EITC expansion led to a 5 percentage point decline in the probability of having an accident for children of low income, married white and Hispanic mothers with two or more EITC-eligible children relative to those with only one EITC-eligible child. For this same group, a parallel calculation reveals that the HOME score increased by 3.86 points. This table also shows a similar economically meaningful pattern for some of the other outcome measures including the HOME (BPI) score for black women which increases (decreases) by 4.65 (11.24) points. However, these simple, unadjusted difference-in-differences calculations do not give us an indication of statistical significance.

Tables 5 and 6 report the main estimation results for the linear probability DD model, for all the outcome measures for children by race/ethnicity and marital status of their mothers. We show only the DD coefficients but all models include the control variables shown in Table $2 .{ }^{20}$ Table 5 presents the DD model without mother fixed effects based

\footnotetext{
${ }^{19}$ Numbers in Table 3 are calculated based on families' earnings in the previous year and the EITC parameters shown in Table 1. Details are available upon request.

${ }^{20}$ The full estimation results are in Appendix Tables 1 - 8 .
} 
on Equation (4.1) and reveals that the EITC expansion significantly increased mother's rating of her child's health for married white and Hispanic mothers and unmarried black mothers. We also find that the quality of the home environment increased for children of white and Hispanic mothers of either marital status and that the children of unmarried white and Hispanic mothers also had better non-cognitive skills. We find no effect of the 1993 EITC expansion on illness or accidents using this simple DD model.

In Table 6, we add the mother fixed effects to our analysis using Equation $(4.2)^{21}$. We see that children of white and Hispanic mothers of either marital status still have higher HOME z-scores after the addition of mother fixed effects to the model. For white and Hispanic children of unmarried mothers, the 5.76 points increase in the HOME z-score is equivalent to 37.6 percent $(5.76 / 15.29)$ of the standard deviation of the HOME z-score (see Table 2), while for white and Hispanic children of married mothers, the 3.32 points increase is equivalent to 24.1 percent $(3.32 / 13.77)$ of the standard deviation. Similarly, mother-rated health for children of married white and Hispanic mothers and unmarried black mothers significantly increased after the 1993 EITC expansion. For children of married white and Hispanic mothers, this increase is equal to 32 percent $(1.19 / 3.71)$ of the average mother-rated health for this group, while for children of unmarried black mothers, this increase is equal to 18 percent $(0.63 / 3.57)$ of the corresponding mean.

The inclusion of mother fixed effects also makes some important changes to the estimation results compared to those presented in Table 5. Specifically, children of white and Hispanic married mothers no longer have a lower BPI score, but they do enjoy a statistically significantly lower accident rate, evidence of protective effect of EITC expansion on children's health possibly through, among other things, an improvement in the quality and/or quantity of child care. These changes highlight the importance of controlling for family-level time-invariant unobserved heterogeneity by including the mother fixed effects which is made possible by our use of longitudinal data.

To bolster our confidence that the estimated $\delta_{d d}$ indeed captures the effects of the

\footnotetext{
${ }^{21}$ Standard errors are clustered at the household/mother level. We have also tried clustering the standard errors at the state level, and our results are robust.
} 
1993 EITC expansion on children's outcomes of interest, we conduct a falsification test where we exclude children of mothers with only one child and focus only on children in the households with two or more EITC-eligible children. Mothers with three or more children will be considered as the 'treatment' group in this case, while those with exactly two children will form the 'control' group. Everything else in this falsification test is the same as in Equation (4.2).

Because the 1993 EITC expansion provides the greatest differential treatment for eligible mothers with one child versus those with two or more children, we should not expect to see any significant effect on children's outcomes of the policy change for the 'treatment' group compared to the 'control' group in this falsification test, because any association of the EITC expansion with the outcomes of interest in this definition of the 'treatment' and 'control' groups would be considered spurious and would call into question similar associations reported in Tables 5 and 6 . This is exactly what we see in Table 7, where again each estimated coefficient is from a separate regression. In addition, the coefficients in these regressions are generally much smaller than those seen in Tables 5 and 6 and despite the necessarily smaller sample sizes and hence the slightly larger standard errors, they truly appear to be indicative of no effect which is what we would expect from this falsification test. It is noteworthy that this falsification test also shows that the effect we capture in Table 6 based on Equation (4.2) is not merely the effect of mothers having another child and thus giving less or more attention to all their children; otherwise children of mothers changing from having two to three or more children would experience significant changes in the outcomes of interest.

In order to take into account the possible dynamic nature of the effects of the 1993 EITC expansion on children's outcomes, we further investigate how these effects changed over time relative to the first year of the policy treatment. Table 8 presents the estimation results. Here, for each outcome measure and each of the four race/ethnicity and parental marital status groups, we report two estimates, the first one is the effect of EITC one year after the policy change became effective (i.e., 1996), and the second one is the effect of the EITC expansion three years after the policy change (i.e., 1998). These numbers 
provide some new and interesting information on exactly how the EITC policy change impacted children in our sample.

For example, the positive effects on mother-rated health and the negative effects on having an accident for white and Hispanic children of married mothers were significant right after the policy change and lasted at least for another three years. The only difference is that for mother-rated health, the effects decreased slightly in magnitude, while for the probability of having an accident, the effects became economically and statistically more significant over time. When we look at the effects of this policy change on HOME scores for white and Hispanic children of unmarried mothers, we find that the policy change did not make an instant impact, but only became significant about three years later. The effects of this policy on HOME scores for children of white and Hispanic married mothers, however, become statistically insignificant, though the magnitude of the effects stay relatively stable. Furthermore, the effect of the 1993 EITC policy change on mother-rated health for children of unmarried black mothers is statistically significant in 1996 but not in 1998.

Finally, it is important to note that the key assumption underlying any DD strategy is that the outcomes of interest in the treatment and the control groups would follow the same trend over time if not for the treatment. Specifically, in our case, we would be concerned if children of mothers with two or more EITC-eligible kids (treatment group) already displayed trends in our outcome variables which were significantly different from those for the children of mothers with only one EITC-eligible kid (control group) prior to the EITC expansion. In that instance, it would be difficult to conclusively assign the changes in our outcome variables to the policy change itself.

To check whether this assumption of non-existence of pre-policy trend indeed holds, we estimate the DD model with the interaction between the treatment status and year 1992 (one year before the policy change), controlling for the same set of covariates as used for the estimations reported in Table $6{ }^{22}$ If those interaction terms between the

\footnotetext{
${ }^{22}$ We cannot include the interaction between the treatment status and year 1990 due to multicollinearity, and we cannot conduct this analysis for mother-rated health because the question used to generate this variable was only asked in 1992, 1996, and 1998 for our sample period.
} 
treatment status and the pre-policy year are significant, then it is important that we control for them to avoid attributing to the EITC expansion any significant changes in our outcome variables that may merely reflect pre-treatment trends; if they are insignificant, then we can be reassured that pre-existing trends are not driving our results and therefore not a concern.

Our results presented in Table 9 provide clear evidence that there exist no pretreatment trends that are different between the treatment and the control groups; that is, the interaction terms between treatment status and the pre-policy year are all statistically insignificant, and our DD estimates all stay unchanged except for that of the HOME score for children of married white and Hispanic mothers which, although has insignificant pre-trend term, is no longer statistically significant. This finding that the interaction term between treatment status and the pre-policy year are insignificant gives us confidence that our results are not merely capturing the effects of some pre-existing trends in our outcomes.

As mentioned earlier, $\$ 480$ extra received by a typical EITC-eligible family with two or more children might not seem substantial in absolute terms. However, our results suggest that at least for this group of children of low-educated mothers, this EITC expansion does matter for their health and the quality of their home environment. These results are consistent with Baker (2008) and Hoynes et al. (2012) who find that the 1993 EITC expansion had statistically significantly increased the birth weight of EITC recipients' children. They are also consistent with findings regarding reduced maternal smoking (Averett and Wang, 2012 and Cowan and Tefft, 2012 ), and improved mental and physical health for female EITC recipients (Evans and Garthwaite, 2014) .

One lingering question is why children of the four different race/ethnicity and marital status groups experienced different changes in their health status and quality of their home environment. One explanation is that qualifying families of different race/ethnicity groups and even different marital status have different EITC take-up rates. ${ }^{23}$ The other

\footnotetext{
${ }^{23}$ See Scholz (1994) for suggestive evidence on the difference in EITC take-up rates by race/ethnicity and marital status.
} 
possibility is that although the EITC expansion works through the same three channels on children's outcomes of interest, the magnitude, significance, and even the sign of these effects may vary by children's race/ethnicity and their parental marital status. And these two points are precisely the reason why we conduct our analysis separately for these groups. ${ }^{24}$

\section{Discussion and Conclusions}

In this research, we analyze whether the EITC, the largest anti-poverty program in the US, also serves to improve children's health, the quality of their home environment, and their non-cognitive skills by exploring an exogenous increase in EITC benefits that occurred in the mid-1990s. Although the policy is not specifically aimed at improving these outcomes, it is possible that it might do so through its effect on income, maternal labor supply and/or maternal health or health behaviors. These potential spillover effects are a potentially important benefit of this program.

The EITC enjoys wide support across the political spectrum and the literature looking into the potential health impacts of the EITC has just been emerging. We contribute to this literature not only by joining the discussion on the potential effects of the EITC on children's health, but also by being the first to analyze the potential effects of the EITC on the quality of children's home environment and their non-cognitive skills. We conduct our analyses separately by race/ethnicity and parental marital status. Our results indicate that the 1993 EITC expansion has statistically significantly improved mother-rated health for children of unmarried black mothers and married white and Hispanic mothers, lowered the probabilities of having accidents for children of married white and Hispanic mothers, and improved home environment quality for children of unmarried white and Hispanic mothers. These results are robust to various specification and falsification checks.

In the past several decades, U.S. poverty relief has become increasingly tied to em-

\footnotetext{
${ }^{24}$ Hoynes et al. (2012), for example, also find different effects of the EITC on birth weight with black mothers seeing much larger effects as compared to white mothers.
} 
ployment, but the consequences for children's wellbeing remain controversial. The EITC, as an income-redistribution policy which encourages labor force participation among the low income population, has enjoyed wide support. Overall our results provide evidence of positive externalities in children's health and the quality of their home environment from the EITC and therefore have potentially important policy implications. 


\section{References}

Adda, Jerome, James Banks, and Hans-Martin von Gaudecker. 2009. “The Impact of Income Shocks on Health: Evidence from Cohort Data.” Journal of the European Economic Association 7(6): 1361-99.

Adler, N. E., and Rehkopf, D. H. 2008. "US disparities in health: descriptions, causes, and mechanisms.” Annual Review of Public Health, 29, 235-252.

Averett, Susan and Yang Wang. 2012. "The Effects of EITC Payment Expansion on Maternal Smoking.” Health Economic, 22(11), 1344 - 1359

Baker, Kevin. 2008. "Do Cash Transfer Programs Improve Infant Health: Evidence from the 1993 Expansion of the Earned Income Tax Credit.” mimeo, University of Notre Dame.

Baughman, Reagan A. 2012. “Effects of State EITC Expansion on Children’s Health”, The Carsey Institute at the Scholars’ Repository. Paper 168.

Baughman, Reagan A, and Dickert-Conlin, Stacy. 2009. "The earned income tax credit and fertility." Journal of Population Economics 22(3):537-563.

Bitler, Marianne, Jonah B. Gelbach, and Hilary W. Hoynes. 2005. "Welfare Reform and Health.” Journal of Human Resources, 40(2): 309-334.

Blackwell, Debra L. 2010. "Family structure and children's health in the United States: findings from the National Health Interview Survey, 2001-2007." Vital and health statistics. Series 10, Data from the National Health Survey 246: 1.

Bradley, R. H. 2003. “Child care and common communicable illnesses in children aged 37 to 54 months.” Archives of pediatrics \& adolescent medicine, 157(2), 196-200.

Burkhauser, Richard, Kenneth Couch and Andrew Glenn. 1996. "Public Policies for the Working-Poor: The Earned Income Tax Credit Versus Minimum Wage Legislation.” Research in Labor Economics 15: 65-109.

Bzostek, Sharon H., and Audrey N. Beck. 2011. "Familial instability and young children’s physical health." Social Science \& Medicine 73, no. 2: 282-292.

Cancian, M. and A. Levinson. 2006. "Labor Supply Effects of the Earned Income Tax Credit: Evidence from Wisconsin’s Supplemental Benefit for Families with Three Children.” National Tax Journal, 59(4): 781-800.

Carneiro, P., Meghir, C., and Parey, M. 2013. "Maternal education, home environments, and the development of children and adolescents.” Journal of the European Economic Association, 11(s1), 123-160. 
Case, A., Lubotsky, D., Paxson, C., 2002. "Economic status and health in childhood: the origins of the gradient.” American Economic Review 92, 1308-1334.

Centers for Disease Control and Prevention. 2000. Growth Charts

(http://www.cdc.gov/nchs/about/major/nhanes/growthcharts/clinical_charts.htm)

Census Bureau. 2014. "Income and Poverty in the United States: 2014” Available at:

http://www.census.gov/content/dam/Census/library/publications/2014/demo/p60-249.pdf. Last accessed 9/18/2014.

Corman, Hope, DM Dave, D Das, and NE Reichman. 2013. "Effects of welfare reform on illicit drug use of adult women." Economic Inquiry 51.1: 653-674.

Cowan, Benjamin, and Nathan Tefft. 2012. "Education, Maternal Smoking, and the Earned Income Tax Credit." The BE Journal of Economic Analysis \& Policy12.1.

Crawford, David, V. Cleland, Anna Timperio, Jo Salmon, Nick Andrianopoulos, R. Roberts, Billie Giles-Corti, Louise Baur, and Kathleen Ball. 2010. "The longitudinal influence of home and neighbourhood environments on children's body mass index and physical activity over 5 years: the CLAN study." International journal of obesity 34, no. 7: 1177-1187.

Carneiro, Pedro, Costas Meghir, and Matthias Parey. 2013. "Maternal education, home environments, and the development of children and adolescents." Journal of the European Economic Association 11.s1: 123-160.

Cunha, F., Heckman, J. J., and Schennach, S. M. 2010. "Estimating the technology of cognitive and noncognitive skill formation.” Econometrica, 78(3), 883-931.

Cunha, F., and Heckman, J. J. 2010. “Investing in our young people.” National Bureau of Economic Research. No. w16201

Currie, Janet. 2005. "Health disparities and gaps in school readiness.” The Future of Children, 15(1), 117-138.

Currie, Janet. 2009. "Healthy, Wealthy, and Wise: Socioeconomic Status, Poor Health in Childhood, and Human Capital Development.” Journal of Economic Literature, 47(1), 87-122.

Currie, J., and Lin, W. 2007. "Chipping away at health: more on the relationship between income and child health.” Health Affairs, 26(2), 331-344.

Currie, Janet and Mark Stabile, 2003."Socioeconomic Status and Child Health: Why Is the Relationship Stronger for Older Children?" American Economic Review, 93(5), 1813-1823.

Currie, Janet, and Mark Stabile. 2006. "Child mental health and human capital accumulation: the case of ADHD." Journal of Health Economics, 25.6: 1094-1118. 
Dahl, Gordon B., and Lance Lochner. 2012 "The impact of family income on child achievement: Evidence from the earned income tax credit." The American Economic Review, 102.5: 19271956.

Deaton, A.S. 2002. "Policy Implications of the Gradient of Health and Wealth," Health Affairs, 21: $13-30$.

Dickert-Conlin, Stacy. 2002. “EITC and Marriage.” National Tax Journal, 55(1): 25-40.

Duncan, G. J., and Brooks-Gunn, J. (2000). Family poverty, welfare reform, and child development. Child development, 71(1), 188-196.

Duncan, Greg J., Chantelle J. Dowsett, Amy Claessens, Katherine Magnuson, Aletha C. Huston, Pamela Klebanov, and Linda S. Pagani. 2007. "School readiness and later achievement." Developmental psychology, 43(6), 1428.

Dunifon, R., Hynes, K., and Peters, H. E. 2006. "Welfare reform and child well-being.” Children and Youth Services Review, 28(11), 1273-1292.

Ege, Markus J., Melanie Mayer, Anne-Cécile Normand, Jon Genuneit, William OCM Cookson, Charlotte Braun-Fahrländer, Dick Heederik, Renaud Piarroux, and Erika von Mutius. 2011. "Exposure to environmental microorganisms and childhood asthma." New England Journal of Medicine 364(8): 701-709.

Eissa, Nada and J. Liebman. 1996. “Labor Supply Response to the Earned Income Tax Credit.” Quarterly Journal of Economics, 111(2): 605-37.

Eissa, Nada, and Hoynes, H. W. 2006. Behavioral responses to taxes: Lessons from the EITC and labor supply. In Tax Policy and the Economy, Volume 20 (pp. 73-110). The MIT Press.

Eissa, Nada, Kleven, HJ, and Kreiner, CT. 2008. "Evaluation of four tax reforms in the United States: Labor supply and welfare effects for single mothers.” Journal of Public Economics, 92(34): 795-816.

Ellwood, David T. 2000. “The Impact of the Earned Income Tax Credit and Social Policy Reforms on Work, Marriage and Living Arrangements.” National Tax Journal. 53(4): 10631005.

Evans, William N., and Graig L. Garthwaite. 2014. "Giving Mom a Break: The Impact of Higher EITC Payments on Maternal Health”, American Economic Journal: Economic Policy, 6(2): 25890.

Gennetian, L. A., Hill, H. D., London, A. S., \& Lopoo, L. M. 2010. “Maternal employment and the health of low-income young children.” Journal of Health Economics, 29(3), 353-363. 
Gordon, R. A., Kaestner, R., and Korenman, S. 2007. “The effects of maternal employment on child injuries and infectious disease”. Demography, 44(2), 307-333.

Grossman, M. 1972, “On the Concept of Health Capital and the Demand for Health.” Journal of Political Economy. 80 (2): 223 - 255.

Heckman, J., J. Stixrud, and S. Urzua (2005). The effects of cognitive and noncognitive abilities on labor market outcomes and social behavior. Journal of Labor Economics 24 (3), 411-482.

Heckman, James J. 2007. "The economics, technology, and neuroscience of human capability formation." Proceedings of the National Academy of Sciences, 104.33: 13250-13255.

Heckman, J., S. H. Moon, R. Pinto, P. Savelyev, and A. Yavitz (2010). Analyzing social experiments as implemented: A reexamination of the evidence from the highscope perry preschool program. Technical Report IZA DP No. 5095, IZA Institute for the Study of Labor.

Hotz, Joseph V. and John Karl Scholz. 2003. “The Earned Income Tax Credit.” In Means-Tested Transfer Programs in the United States, Robert Moffitt, ed. Chicago: The University of Chicago Press and the NBER, 141-197.

Hotz, V. Joseph, and John Karl Scholz. 2006 "Examining the effect of the earned income tax credit on the labor market participation of families on welfare". No. w11968. National Bureau of Economic Research,.

Hoynes, Hilary W., Douglas L. Miller, and David Simon. 2012. "Income, the Earned Income Tax Credit, and Infant Health”. NBER Working Paper No. 18206.

Klein, J. (2003). The natural: The misunderstood presidency of Bill Clinton. Random House LLC.

Leonard, J., and Mas, A. 2008. "Welfare reform, time limits, and infant health”. Journal of health economics, 27(6), 1551-1566.

Maher, E. J., Li, G., Carter, L., and Johnson, D. B. 2008. "Preschool child care participation and obesity at the start of kindergarten.” Pediatrics, 122(2), 322-330.

Meyer, Bruce D. 2010. "The Effects of the Earned Income Tax Credit and Recent Reforms.” Chapter in NBER book Tax Policy and the Economy, Volume 24, Jeffrey R. Brown, editor. p. $153-180$.

Meyer, Bruce D., and Dan T. Rosenbaum. 2001. "Welfare, the Earned Income Tax Credit, and the Labor Supply of Single Mothers.” Quarterly Journal of Economics, 116(3): 1063-1114.

McLanahan, Sara. 2004 "Diverging destinies: How children are faring under the second demographic transition." Demography 41.4: 607-627. 
Miller, Amalia R., and Lei Zhang. 2009. "The Effects of Welfare Reform on the Academic Performance of Children in Low-Income Households.” Journal of Policy Analysis and Management, 28(4): 577-599.

Morrill, M. S. 2011. "The effects of maternal employment on the health of school-age children," Journal of Health Economics, 30(2), 240-257.

Neumark, David and William Wascher. 2001. "Using the EITC to help Poor Families: New Evidence and a Comparison with the Minimum Wage.” National Tax Journal, 54(2): 281-317.

OECD. 2009. "Comparative Child Well-Being Across the OECD.” Available at: http://www.oecd.org/social/family/43570328.pdf. Last accessed 9/18/2014.

Ribar, David C. 2004. "What do social scientists know about the benefits of marriage?: A review of quantitative methodologies”. No. 998. IZA Discussion paper series.

Schmeiser, M. 2009. "Expanding Wallets and Waistlines: The Impact of Family Income on the BMI of Women and Men Eligible for the Earned Income Tax Credit.” Health Economics, 18(11): 1277-84.

Scholz, John Karl. 1994. "The Earned Income Tax Credit: Participation, Compliance, and AntiPoverty Effectiveness.” National Tax Journal, 47(1): 59-81.

Strully, K. W., Rehkopf, D. H., and Xuan, Z. 2010. "Effects of Prenatal Poverty on Infant Health State Earned Income Tax Credits and Birth Weight”. American sociological review, 75(4), 534562.

Todd, P. E., and Wolpin, K. I. 2007. "The production of cognitive achievement in children: Home, school, and racial test score gaps.” Journal of Human Capital, 1(1), 91-136. 
Table 1. Earned Income Tax Credit Parameters, 1975-2000 (Dollar amounts unadjusted for inflation)

\begin{tabular}{|c|c|c|c|c|c|c|}
\hline \multirow[b]{2}{*}{$\begin{array}{c}\text { Calendar } \\
\text { Year } \\
\end{array}$} & \multirow[b]{2}{*}{$\begin{array}{c}\text { Credit } \\
\text { rate } \\
\text { (percent) } \\
\end{array}$} & \multirow{2}{*}{$\begin{array}{c}\text { Minimum } \\
\text { income for } \\
\text { maximum } \\
\text { credit }\end{array}$} & \multirow[b]{2}{*}{$\begin{array}{c}\text { Maximum } \\
\text { credit }\end{array}$} & \multirow[b]{2}{*}{$\begin{array}{c}\text { Phaseout } \\
\text { Rate } \\
\text { (percent) }\end{array}$} & \multicolumn{2}{|c|}{ Phaseout range } \\
\hline & & & & & $\begin{array}{c}\text { Beginning } \\
\text { income }\end{array}$ & $\begin{array}{l}\text { Ending } \\
\text { income }\end{array}$ \\
\hline $1975-78$ & 10 & 4,000 & 400 & 10 & 4,000 & 8,000 \\
\hline 1979-84 & 10 & 5,000 & 500 & 12.5 & 6,000 & 10,000 \\
\hline 1985-86 & 11 & 5,000 & 550 & 12.22 & 6,500 & 11,000 \\
\hline 1987 & 14 & 6,080 & 851 & 10 & 6,920 & 15,432 \\
\hline 1988 & 14 & 6,240 & 874 & 10 & 9,840 & 18,576 \\
\hline 1989 & 14 & 6,500 & 910 & 10 & 10,240 & 19,340 \\
\hline 1990 & 14 & 6,810 & 953 & 10 & 10,730 & 20,264 \\
\hline \multicolumn{7}{|l|}{1991} \\
\hline One child & 16.7 & 7,140 & 1,192 & 11.93 & 11,250 & 21,250 \\
\hline Two children & 17.3 & 7,140 & 1,235 & 12.36 & 11,250 & 21,250 \\
\hline \multicolumn{7}{|l|}{1992} \\
\hline One child & 17.6 & 7,520 & 1,324 & 12.57 & 11,840 & 22,370 \\
\hline Two children & 18.4 & 7,520 & 1,384 & 13.14 & 11,840 & 22,370 \\
\hline \multicolumn{7}{|l|}{1993} \\
\hline One child & 18.5 & 7,750 & 1,434 & 13.21 & 12,200 & 23,050 \\
\hline Two children & 19.5 & 7,750 & 1,511 & 13.93 & 12,200 & 23,050 \\
\hline \multicolumn{7}{|l|}{1994} \\
\hline One child & 26.3 & 7,750 & 2,038 & 15.98 & 11,000 & 23,755 \\
\hline Two children & 30 & 8,425 & 2,528 & 17.68 & 11,000 & 25,296 \\
\hline \multicolumn{7}{|l|}{1995} \\
\hline One child & 34 & 6,160 & 2,094 & 15.98 & 11,290 & 24,396 \\
\hline Two children & 36 & 8,640 & 3,110 & 20.22 & 11,290 & 26,673 \\
\hline \multicolumn{7}{|l|}{1996} \\
\hline One child & 34 & 6,330 & 2,152 & 15.98 & 11,610 & 25,078 \\
\hline Two children & 40 & 8,890 & 3,556 & 21.06 & 11,610 & 28,495 \\
\hline \multicolumn{7}{|l|}{1997} \\
\hline One child & 34 & 6,500 & 2,210 & 15.98 & 11,930 & 25,750 \\
\hline Two children & 40 & 9,140 & 3,656 & 21.06 & 11,930 & 29,290 \\
\hline \multicolumn{7}{|l|}{1998} \\
\hline One child & 34 & 6,680 & 2,271 & 15.98 & 12,260 & 26,473 \\
\hline Two children & 40 & 9,390 & 3,756 & 21.06 & 12,260 & 30,095 \\
\hline \multicolumn{7}{|l|}{1999} \\
\hline One child & 34 & 6,800 & 2,312 & 15.98 & 12,460 & 26,928 \\
\hline Two children & 40 & 9,540 & 3,816 & 21.06 & 12,460 & 30,580 \\
\hline \multicolumn{7}{|l|}{2000} \\
\hline One child & 34 & 6,920 & 2,353 & 15.98 & 12,690 & 27,413 \\
\hline Two children & 40 & 9,720 & 3,888 & 21.06 & 12,690 & 31,152 \\
\hline
\end{tabular}


Table 2. Sample Means

\begin{tabular}{|c|c|c|c|c|c|c|c|c|c|c|c|c|}
\hline \multirow[b]{2}{*}{ Variable } & \multicolumn{3}{|c|}{ Married } & \multicolumn{3}{|c|}{ Unmarried } & \multicolumn{3}{|c|}{ Married } & \multicolumn{3}{|c|}{ Unmarried } \\
\hline & Full Sample & $\begin{array}{l}2+\text { EITC } \\
\text { elig kid }\end{array}$ & $\begin{array}{l}1 \text { EITC elig } \\
\text { kid }\end{array}$ & Full Sample & $\begin{array}{l}2+\text { EITC } \\
\text { elig kid }\end{array}$ & $\begin{array}{l}1 \text { EITC elig } \\
\text { kid }\end{array}$ & Full Sample & $\begin{array}{l}2+\text { EITC } \\
\text { elig kid }\end{array}$ & $\begin{array}{l}1 \text { EITC elig } \\
\text { kid }\end{array}$ & Full Sample & $\begin{array}{l}2+\text { EITC } \\
\text { elig kid }\end{array}$ & $\begin{array}{l}1 \text { EITC elig } \\
\text { kid }\end{array}$ \\
\hline \multirow[t]{2}{*}{ Mother's health rating } & 3.71 & 3.70 & 3.79 & 3.57 & 3.56 & 3.68 & 3.70 & 3.71 & 3.68 & 3.58 & 3.57 & 3.64 \\
\hline & $(0.51)$ & $(0.51)$ & $(0.43)$ & $(0.62)$ & $(0.63)$ & $(0.47)$ & $(0.52)$ & $(0.52)$ & $(0.50)$ & $(0.58)$ & $(0.59)$ & $(0.50)$ \\
\hline Illness w/ medical attention & 0.22 & 0.22 & 0.19 & 0.19 & 0.19 & 0.25 & 0.38 & 0.37 & 0.55 & 0.35 & 0.32 & 0.48 \\
\hline Accident past yr & 0.07 & 0.07 & 0.10 & 0.07 & 0.07 & 0.08 & 0.11 & 0.11 & 0.11 & 0.14 & 0.14 & 0.13 \\
\hline \multirow[t]{2}{*}{ Home score } & 93.98 & 93.78 & 99.06 & 80.61 & 80.02 & 90.62 & 99.95 & 99.64 & 103.94 & 89.25 & 88.09 & 95.20 \\
\hline & (14.73) & (14.73) & (14.05) & $(17.27)$ & $(17.18)$ & (15.79) & $(13.77)$ & $(13.87)$ & $(11.76)$ & (15.29) & (15.33) & (13.59) \\
\hline \multirow[t]{2}{*}{ BPI } & 106.05 & 106.03 & 106.62 & 109.50 & 109.48 & 109.70 & 105.00 & 105.03 & 104.69 & 109.11 & 108.95 & 109.88 \\
\hline & $(14.01)$ & (13.93) & (16.18) & (15.91) & (15.96) & (15.26) & (14.39) & $(14.50)$ & (12.87) & (15.58) & $(15.90)$ & $(13.85)$ \\
\hline \multirow[t]{2}{*}{ Age of child, year } & 7.36 & 7.32 & 8.38 & 7.46 & 7.47 & 7.30 & 7.32 & 7.36 & 6.86 & 7.73 & 7.73 & 7.70 \\
\hline & (3.74) & (3.73) & (3.95) & (3.66) & (3.65) & (3.82) & (3.65) & (3.65) & $(3.71)$ & (3.56) & (3.55) & $(3.61)$ \\
\hline Child is male & 0.48 & 0.48 & 0.48 & 0.49 & 0.50 & 0.39 & 0.52 & 0.53 & 0.43 & 0.50 & 0.50 & 0.47 \\
\hline \multirow[t]{2}{*}{ Mom's age } & 31.54 & 31.56 & 31.19 & 31.98 & 31.97 & 32.03 & 32.60 & 32.62 & 32.35 & 32.18 & 32.26 & 31.77 \\
\hline & $(3.56)$ & $(3.55)$ & $(3.72)$ & (3.57) & (3.59) & $(3.28)$ & (3.58) & $(3.57)$ & $(3.76)$ & (3.66) & (3.67) & (3.59) \\
\hline \multirow[t]{2}{*}{ \# EITC elig kids in HH } & 2.94 & 3.02 & 1.00 & 3.12 & 3.24 & 1.00 & 2.71 & 2.84 & 1.00 & 2.53 & 2.84 & 1.00 \\
\hline & (1.09) & $(1.05)$ & $(0.00)$ & (1.38) & $(1.32)$ & $(0.00)$ & $(1.14)$ & $(1.08)$ & 0.00 & $(1.17)$ & (1.04) & 0.00 \\
\hline \multirow[t]{2}{*}{ Mom's educ. years } & 11.70 & 11.69 & 11.94 & 11.23 & 11.20 & 11.73 & 11.35 & 11.32 & 11.70 & 11.21 & 11.17 & 11.39 \\
\hline & $(0.85)$ & $(0.86)$ & $(0.25)$ & $(1.24)$ & $(1.26)$ & $(0.64)$ & $(1.62)$ & (1.65) & $(1.11)$ & $(1.64)$ & $(1.72)$ & $(1.12)$ \\
\hline \multirow[t]{2}{*}{ State AFDC ben. \$K } & 0.34 & 0.34 & 0.33 & 0.35 & 0.35 & 0.34 & 0.45 & 0.46 & 0.40 & 0.48 & 0.49 & 0.45 \\
\hline & $(0.15)$ & $(0.15)$ & $(0.13)$ & $(0.15)$ & $(0.15)$ & $(0.14)$ & $(0.18)$ & $(0.18)$ & $(0.17)$ & $(0.19)$ & $(0.19)$ & $(0.18)$ \\
\hline \multirow[t]{2}{*}{ State unemp. rate } & 5.70 & 5.71 & 5.35 & 5.83 & 5.83 & 5.93 & 5.97 & 5.98 & 5.77 & 6.14 & 6.16 & 6.00 \\
\hline & $(1.41)$ & $(1.41)$ & $(1.46)$ & $(1.45)$ & $(1.44)$ & $(1.56)$ & (1.63) & (1.63) & $(1.61)$ & $(1.62)$ & $(1.62)$ & $(1.62)$ \\
\hline \multirow[t]{2}{*}{ Medicaid elig. Cutoff \$ } & 152.34 & 152.61 & 145.35 & 152.67 & 152.49 & 155.56 & 159.22 & 159.24 & 159.01 & 162.17 & 162.72 & 159.43 \\
\hline & $(24.30)$ & $(24.45)$ & (18.86) & (24.28) & (24.19) & (25.66) & (24.43) & $(24.47)$ & $(23.90)$ & (24.18) & (24.06) & (24.63) \\
\hline Mother Hispanic & & & & & & & 0.30 & 0.31 & 0.15 & 0.45 & 0.47 & 0.35 \\
\hline Observations & 869 & 838 & 31 & 1695 & 1599 & 96 & 3897 & 3613 & 284 & 1571 & 1309 & 262 \\
\hline
\end{tabular}


Table 3. Real EITC Benefits for EITC Eligible Women in Our Sample by Number of EITC Eligible Children in Household

\begin{tabular}{l|l|l}
\hline & \multicolumn{2}{|c}{ Years of Education $\leq 12$} \\
\hline Calculated EITC benefits (1992 \$) & One EITC eligible kid & 2+ EITC eligible kids \\
\hline 1990 & 496.2323 & 358.5922 \\
& $(671.6514)$ & $(597.0229)$ \\
\hline 1992 & 779.9894 & 571.5343 \\
& $(959.6946)$ & $(898.1539)$ \\
\hline 1996 & 1008.877 & 1416.577 \\
& $(1328.908)$ & $(1909.17)$ \\
\hline 1998 & 1064.27 & 1339.328 \\
& $(1422.023)$ & $(1988.183)$ \\
\hline
\end{tabular}

Source: Author's calculations from the NLSY79. Standard deviations are in the brackets. 
Table 4: Sample Means

Black, Married

\begin{tabular}{|c|c|c|c|c|c|c|c|c|}
\hline Variable & $\begin{array}{l}2+ \\
\text { EITC } \\
\text { elig. } \\
\text { kids, } \\
\text { before } \\
\end{array}$ & $\begin{array}{l}2+ \\
\text { EITC } \\
\text { elig. } \\
\text { kids, } \\
\text { after }\end{array}$ & $\begin{array}{l}1 \text { EITC } \\
\text { elig. } \\
\text { kid, } \\
\text { before }\end{array}$ & $\begin{array}{l}1 \text { EITC } \\
\text { elig. } \\
\text { kid, } \\
\text { after }\end{array}$ & $\begin{array}{l}2+ \\
\text { EITC } \\
\text { elig. } \\
\text { kids, } \\
\text { before }\end{array}$ & $\begin{array}{l}2+ \\
\text { EITC } \\
\text { elig. } \\
\text { kids, } \\
\text { after }\end{array}$ & $\begin{array}{l}1 \text { EITC } \\
\text { elig. } \\
\text { kid, } \\
\text { before }\end{array}$ & $\begin{array}{l}1 \text { EITC } \\
\text { elig. } \\
\text { kid, } \\
\text { after }\end{array}$ \\
\hline Illness $\mathrm{w} /$ medical attention & 0.26 & 0.17 & 0.18 & 0.21 & 0.22 & 0.15 & 0.25 & 0.24 \\
\hline Accident in past year & 0.09 & 0.05 & 0.12 & 0.07 & 0.07 & 0.07 & 0.04 & 0.13 \\
\hline Home score & $\begin{array}{r}93.57 \\
(14.76)\end{array}$ & $\begin{array}{r}94.08 \\
(14.71)\end{array}$ & $\begin{array}{c}100.99 \\
(17.05)\end{array}$ & $\begin{array}{l}96.85 \\
(9.75)\end{array}$ & $\begin{array}{r}79.98 \\
(16.99)\end{array}$ & $\begin{array}{r}80.06 \\
(17.40)\end{array}$ & $\begin{array}{r}91.17 \\
(15.38)\end{array}$ & $\begin{array}{r}90.06 \\
(16.35)\end{array}$ \\
\hline BPI & $\begin{array}{r}106.33 \\
(13.67)\end{array}$ & $\begin{array}{r}105.75 \\
(14.18)\end{array}$ & $\begin{array}{r}101.92 \\
(16.60)\end{array}$ & $\begin{array}{r}111.31 \\
(14.91)\end{array}$ & $\begin{array}{r}109.42 \\
(15.69)\end{array}$ & $\begin{array}{c}109.53 \\
(16.18)\end{array}$ & $\begin{array}{r}111 \\
(13.04)\end{array}$ & $\begin{array}{l}108.84 \\
(16.65)\end{array}$ \\
\hline Mother's health rating & $\begin{array}{r}3.61 \\
(0.70)\end{array}$ & $\begin{array}{r}3.71 \\
(0.50)\end{array}$ & & $\begin{array}{r}3.79 \\
(0.43)\end{array}$ & $\begin{array}{r}3.49 \\
(0.68)\end{array}$ & $\begin{array}{r}3.57 \\
(0.62)\end{array}$ & $\begin{array}{r}4.00 \\
(0.00)\end{array}$ & $\begin{array}{r}3.66 \\
(0.48)\end{array}$ \\
\hline Observations & 490 & 348 & 17 & 14 & 867 & 732 & 51 & 45 \\
\hline & & \multicolumn{3}{|c|}{ White and Hispanic, Married } & \multicolumn{4}{|c|}{ White and Hispanic, Unmarried } \\
\hline Illness $\mathrm{w} /$ medical attention & 0.44 & 0.29 & 0.63 & 0.46 & 0.39 & 0.23 & 0.56 & 0.39 \\
\hline Accident in past year & 0.10 & 0.12 & 0.08 & 0.15 & 0.12 & 0.16 & 0.12 & 0.15 \\
\hline Home score & $\begin{array}{r}99.76 \\
(13.94)\end{array}$ & $\begin{array}{r}99.50 \\
(13.79)\end{array}$ & $\begin{array}{r}105.95 \\
(11.54)\end{array}$ & $\begin{array}{r}101.84 \\
(11.65)\end{array}$ & $\begin{array}{r}88.36 \\
(15.70)\end{array}$ & $\begin{array}{r}87.78 \\
(14.89)\end{array}$ & $\begin{array}{r}97.21 \\
(12.95)\end{array}$ & $\begin{array}{r}92.74 \\
(14.00)\end{array}$ \\
\hline BPI & $\begin{array}{r}104.82 \\
(14.37)\end{array}$ & $\begin{array}{c}105.19 \\
(14.60)\end{array}$ & $\begin{array}{r}102.23 \\
(11.75)\end{array}$ & $\begin{array}{r}106.14 \\
(13.31)\end{array}$ & $\begin{array}{r}109.31 \\
(15.32)\end{array}$ & $\begin{array}{r}108.64 \\
(16.41)\end{array}$ & $\begin{array}{r}110.73 \\
(12.89)\end{array}$ & $\begin{array}{l}109.09 \\
(14.71)\end{array}$ \\
\hline Mother's health rating & $\begin{array}{r}3.54 \\
(0.66)\end{array}$ & $\begin{array}{r}3.71 \\
(0.51)\end{array}$ & $\begin{array}{r}4.00 \\
(0.00)\end{array}$ & $\begin{array}{r}3.67 \\
(0.51)\end{array}$ & $\begin{array}{r}3.59 \\
(0.67)\end{array}$ & $\begin{array}{r}3.57 \\
(0.59)\end{array}$ & $\begin{array}{r}3.71 \\
(0.49)\end{array}$ & $\begin{array}{r}3.63 \\
(0.50)\end{array}$ \\
\hline Observations & 1956 & 1657 & 148 & 136 & 725 & 584 & 145 & 117 \\
\hline
\end{tabular}

Standard deviations of continuous variables in parentheses. 
Table 5. DD by Race/Ethnicity and Maternal Marital Status

\begin{tabular}{|c|c|c|c|c|c|}
\hline VARIABLES & $\begin{array}{c}\text { Mother-Rated } \\
\text { Health }\end{array}$ & Illness & Accident & $\begin{array}{l}\text { HOME } \\
\text { Z-Score }\end{array}$ & $\begin{array}{c}\text { BPI } \\
\text { Z-Score }\end{array}$ \\
\hline \multicolumn{6}{|c|}{ White + Hispanic, Unmarried } \\
\hline 2+ EITC kids*after & $\begin{array}{c}0.1237 \\
(0.2548)\end{array}$ & $\begin{array}{c}0.0403 \\
(0.0656)\end{array}$ & $\begin{array}{l}-0.0102 \\
(0.0404)\end{array}$ & $\begin{array}{c}4.5459 * * \\
(2.0295)\end{array}$ & $\begin{array}{c}1.1280 \\
(2.1266)\end{array}$ \\
\hline Observations & 690 & 1,553 & 1,564 & 1,492 & 1,273 \\
\hline R-squared & 0.1072 & 0.1338 & 0.0763 & 0.1674 & 0.1135 \\
\hline \multicolumn{6}{|c|}{ White + Hispanic, Married } \\
\hline 2+ EITC kids*after & $\begin{array}{c}0.6191 * * * \\
(0.1581)\end{array}$ & $\begin{array}{c}0.0167 \\
(0.0597)\end{array}$ & $\begin{array}{l}-0.0540 \\
(0.0400)\end{array}$ & $\begin{array}{c}4.3650 * * * \\
(1.4692)\end{array}$ & $\begin{array}{c}-3.9583 * * \\
(1.9551)\end{array}$ \\
\hline Observations & 1,720 & 3,812 & 3,852 & 3,656 & 2,992 \\
\hline R-squared & 0.0911 & 0.1033 & 0.0290 & 0.1813 & 0.0867 \\
\hline \multicolumn{6}{|l|}{ Black, Unmarried } \\
\hline 2+ EITC kids*after & $\begin{array}{c}0.4277 * * \\
(0.2018)\end{array}$ & $\begin{array}{l}-0.0642 \\
(0.0889)\end{array}$ & $\begin{array}{l}-0.0914 \\
(0.0721)\end{array}$ & $\begin{array}{c}2.5362 \\
(2.7128)\end{array}$ & $\begin{array}{c}1.6506 \\
(3.1389)\end{array}$ \\
\hline Observations & 747 & 1,677 & 1,693 & 1,599 & 1,293 \\
\hline R-squared & 0.1175 & 0.0761 & 0.0425 & 0.1934 & 0.1272 \\
\hline \multicolumn{6}{|l|}{ Black, Married } \\
\hline 2+ EITC kids*after & $\begin{array}{l}-0.0734 \\
(0.4038)\end{array}$ & $\begin{array}{l}-0.2265 \\
(0.1188)\end{array}$ & $\begin{array}{l}-0.0052 \\
(0.1146)\end{array}$ & $\begin{array}{c}8.7744 \\
(5.3915)\end{array}$ & $\begin{array}{l}-7.1026 \\
(4.5377)\end{array}$ \\
\hline Observations & 352 & 858 & 866 & 816 & 648 \\
\hline R-squared & 0.1422 & 0.0999 & 0.0599 & 0.1374 & 0.1677 \\
\hline
\end{tabular}

Robust standard errors in parentheses. All Models include state fixed effects and year dummies. $* * * \mathbf{p}<0.01, * * \mathbf{p}<0.05$

Each cell represents a separate regression and each regression includes the full set of controls shown in Table 2 plus state fixed effects. 
Table 6. DD + Mother FE by Race/Ethnicity and Maternal Marital Status

\begin{tabular}{|c|c|c|c|c|c|}
\hline VARIABLES & $\begin{array}{l}\text { Mother-Rated } \\
\text { Health }\end{array}$ & Illness & Accident & $\begin{array}{l}\text { HOME } \\
\text { Z-Score }\end{array}$ & $\begin{array}{c}\text { BPI } \\
\text { Z-Score }\end{array}$ \\
\hline \multicolumn{6}{|c|}{ White + Hispanic, Unmarried } \\
\hline 2+ EITC kids*after & $\begin{array}{l}-0.1913 \\
(0.2888)\end{array}$ & $\begin{array}{c}0.0778 \\
(0.0729)\end{array}$ & $\begin{array}{l}-0.0130 \\
(0.0405)\end{array}$ & $\begin{array}{c}5.7593 * * \\
(2.3054)\end{array}$ & $\begin{array}{c}1.1535 \\
(2.1070)\end{array}$ \\
\hline Observations & 690 & 1,553 & 1,564 & 1,492 & 1,273 \\
\hline R-squared & 0.0595 & 0.0663 & 0.0391 & 0.0517 & 0.0587 \\
\hline Number of ID & 302 & 424 & 424 & 420 & 407 \\
\hline \multicolumn{6}{|c|}{ White + Hispanic, Married } \\
\hline 2+ EITC kids*after & $\begin{array}{c}1.1901 * * * \\
(0.0980)\end{array}$ & $\begin{array}{l}-0.0177 \\
(0.0688)\end{array}$ & $\begin{array}{c}-0.1342 * * * \\
(0.0439)\end{array}$ & $\begin{array}{c}3.3210 * * \\
(1.5233)\end{array}$ & $\begin{array}{c}1.7261 \\
(1.7847)\end{array}$ \\
\hline Observations & 1,720 & 3,812 & 3,852 & 3,656 & 2,992 \\
\hline R-squared & 0.0402 & 0.0549 & 0.0309 & 0.0547 & 0.0571 \\
\hline Number of ID & 638 & 780 & 781 & 770 & 744 \\
\hline \multicolumn{6}{|l|}{ Black, Unmarried } \\
\hline 2+ EITC kids*after & $\begin{array}{c}0.6320 * * \\
(0.3042)\end{array}$ & $\begin{array}{c}-0.0704 \\
(0.1025)\end{array}$ & $\begin{array}{l}-0.0964 \\
(0.0863)\end{array}$ & $\begin{array}{c}3.3524 \\
(2.5787)\end{array}$ & $\begin{array}{l}-2.1230 \\
(2.7601)\end{array}$ \\
\hline Observations & 747 & 1,677 & 1,693 & 1,599 & 1,293 \\
\hline R-squared & 0.0162 & 0.0423 & 0.0353 & 0.0475 & 0.0503 \\
\hline Number of ID & 268 & 319 & 319 & 319 & 312 \\
\hline \multicolumn{6}{|l|}{ Black, Married } \\
\hline 2+ EITC kids*after & $\begin{array}{c}0.2673 \\
(0.6088)\end{array}$ & $\begin{array}{l}-0.0385 \\
(0.1595)\end{array}$ & $\begin{array}{c}-0.0743 \\
(0.1296)\end{array}$ & $\begin{array}{c}2.4016 \\
(7.1041)\end{array}$ & $\begin{array}{l}-3.6938 \\
(4.9184)\end{array}$ \\
\hline Observations & 352 & 858 & 866 & 816 & 648 \\
\hline R-squared & 0.0785 & 0.0537 & 0.0908 & 0.1181 & 0.1014 \\
\hline Number of ID & 133 & 196 & 197 & 194 & 182 \\
\hline
\end{tabular}

Robust standard errors in parentheses. All Models include state fixed effects and year dummies. $* * * \mathbf{p}<0.01, * *$
epresents a separate regression and each regression includes the full set of controls shown in Table 2 plus state fixed effects. 
Table 7. Falsification Test: 2 Kids vs. $3+$ Kids

\begin{tabular}{|c|c|c|c|c|c|}
\hline VARIABLES & $\begin{array}{c}\text { Mother-Rated } \\
\text { Health } \\
\end{array}$ & Illness & Accident & $\begin{array}{l}\text { HOME } \\
\text { Z-Score }\end{array}$ & $\begin{array}{c}\text { BPI } \\
\text { Z-Score }\end{array}$ \\
\hline \multicolumn{6}{|c|}{ White + Hispanic, Unmarried } \\
\hline 3+ EITC kids*after & $\begin{array}{c}0.5614 \\
(0.3172)\end{array}$ & $\begin{array}{c}0.0705 \\
(0.0714)\end{array}$ & $\begin{array}{l}-0.0510 \\
(0.0480)\end{array}$ & $\begin{array}{c}4.7566 \\
(2.7095)\end{array}$ & $\begin{array}{l}-2.6460 \\
(2.2981)\end{array}$ \\
\hline Observations & 577 & 1,290 & 1,301 & 1,246 & 1,060 \\
\hline R-squared & 0.0697 & 0.0654 & 0.0338 & 0.0549 & 0.0667 \\
\hline Number of ID & 219 & 313 & 313 & 309 & 304 \\
\hline \multicolumn{6}{|c|}{ White + Hispanic, Married } \\
\hline 3+ EITC kids*after & $\begin{array}{c}-0.0739 \\
(0.1769)\end{array}$ & $\begin{array}{c}-0.0292 \\
(0.0412)\end{array}$ & $\begin{array}{l}-0.0091 \\
(0.0242)\end{array}$ & $\begin{array}{c}0.8422 \\
(1.1182)\end{array}$ & $\begin{array}{l}-0.1427 \\
(1.0593)\end{array}$ \\
\hline Observations & 1,589 & 3,527 & 3,564 & 3,384 & 2,778 \\
\hline R-squared & 0.0375 & 0.0578 & 0.0282 & 0.0599 & 0.0595 \\
\hline Number of ID & 548 & 663 & 664 & 658 & 639 \\
\hline \multicolumn{6}{|l|}{ Black, Unmarried } \\
\hline 3+ EITC kids*after & $\begin{array}{l}-0.2017 \\
(0.2417)\end{array}$ & $\begin{array}{l}-0.0706 \\
(0.0502)\end{array}$ & $\begin{array}{l}-0.0196 \\
(0.0272)\end{array}$ & $\begin{array}{l}-0.9259 \\
(2.4181)\end{array}$ & $\begin{array}{l}-1.7050 \\
(2.3206)\end{array}$ \\
\hline Observations & 706 & 1,581 & 1,597 & 1,510 & 1,220 \\
\hline R-squared & 0.0136 & 0.0480 & 0.0352 & 0.0486 & 0.0540 \\
\hline Number of ID & 242 & 284 & 284 & 284 & 277 \\
\hline \multicolumn{6}{|l|}{ Black, Married } \\
\hline 3+ EITC kids*after & $\begin{array}{c}-0.3003 \\
(0.2137)\end{array}$ & $\begin{array}{c}0.1336 \\
(0.0835)\end{array}$ & $\begin{array}{c}0.0178 \\
(0.0510)\end{array}$ & $\begin{array}{c}-1.1074 \\
(2.8139)\end{array}$ & $\begin{array}{c}2.9335 \\
(2.7257)\end{array}$ \\
\hline Observations & 338 & 827 & 835 & 786 & 622 \\
\hline R-squared & 0.0904 & 0.0565 & 0.1020 & 0.1316 & 0.1043 \\
\hline Number of ID & 124 & 179 & 180 & 178 & 168 \\
\hline
\end{tabular}

Robust standard errors in parentheses. All models control for state fixed effects and year dummies. $* * * \mathbf{p}<0.01, * *$ p $<0.05$

Each cell represents a separate regression and each regression includes the full set of controls shown in Table 2 plus state fixed effects. 
Table 8. DD + Mother FE with Lagged Treatment Effects

\begin{tabular}{|c|c|c|c|c|c|}
\hline VARIABLES & $\begin{array}{l}\text { Mother-Rated } \\
\text { Health }\end{array}$ & Illness & Accident & $\begin{array}{l}\text { HOME } \\
\text { Z-Score }\end{array}$ & $\begin{array}{c}\text { BPI } \\
\text { Z-Score }\end{array}$ \\
\hline \multicolumn{6}{|c|}{ White + Hispanic, Unmarried } \\
\hline 2+ EITC kids*1996 & $\begin{array}{l}-0.1869 \\
(0.2900)\end{array}$ & $\begin{array}{c}0.0687 \\
(0.0821)\end{array}$ & $\begin{array}{l}-0.0174 \\
(0.0489)\end{array}$ & $\begin{array}{c}4.1987 \\
(2.5471)\end{array}$ & $\begin{array}{c}0.3823 \\
(2.2251)\end{array}$ \\
\hline 2+ EITC kids*1998 & $\begin{array}{l}-0.2538 \\
(0.3127)\end{array}$ & $\begin{array}{c}0.0842 \\
(0.1029)\end{array}$ & $\begin{array}{c}0.0107 \\
(0.0754)\end{array}$ & $\begin{array}{c}8.5504 * * * \\
(2.5907)\end{array}$ & $\begin{array}{c}3.3950 \\
(2.9526)\end{array}$ \\
\hline R-squared & 0.0600 & 0.0651 & 0.0380 & 0.0522 & 0.0594 \\
\hline \multicolumn{6}{|c|}{ White + Hispanic, Married } \\
\hline 2+ EITC kids*1996 & $\begin{array}{c}1.1896 * * * \\
(0.0980)\end{array}$ & $\begin{array}{c}0.0063 \\
(0.0778)\end{array}$ & $\begin{array}{c}-0.0985 * * \\
(0.0460)\end{array}$ & $\begin{array}{c}3.2207 \\
(1.6486)\end{array}$ & $\begin{array}{c}1.7120 \\
(1.7459)\end{array}$ \\
\hline 2+ EITC kids*1998 & $\begin{array}{c}1.1169 * * * \\
(0.1252)\end{array}$ & $\begin{array}{l}-0.0616 \\
(0.0862)\end{array}$ & $\begin{array}{c}-0.2011 * * * \\
(0.0712)\end{array}$ & $\begin{array}{c}3.4880 \\
(2.1515)\end{array}$ & $\begin{array}{c}1.7612 \\
(2.2487)\end{array}$ \\
\hline R-squared & 0.0407 & 0.0551 & 0.0318 & 0.0547 & 0.0571 \\
\hline \multicolumn{6}{|l|}{ Black, Unmarried } \\
\hline 2+ EITC kids*1996 & $\begin{array}{c}0.6089 * * \\
(0.2984)\end{array}$ & $\begin{array}{l}-0.1650 \\
(0.1026)\end{array}$ & $\begin{array}{l}-0.0835 \\
(0.0824)\end{array}$ & $\begin{array}{c}4.3755 \\
(2.8205)\end{array}$ & $\begin{array}{l}-3.5120 \\
(3.2165)\end{array}$ \\
\hline 2+ EITC kids*1998 & $\begin{array}{c}0.5109 \\
(0.3361)\end{array}$ & $\begin{array}{c}0.1685 \\
(0.1398)\end{array}$ & $\begin{array}{l}-0.1277 \\
(0.1194)\end{array}$ & $\begin{array}{c}1.0254 \\
(4.2318)\end{array}$ & $\begin{array}{c}0.6685 \\
(3.3761)\end{array}$ \\
\hline R-squared & 0.0153 & 0.0470 & 0.0313 & 0.0476 & 0.0511 \\
\hline \multicolumn{6}{|l|}{ Black, Married } \\
\hline 2+ EITC kids*1996 & $\begin{array}{c}0.0966 \\
(0.6484)\end{array}$ & $\begin{array}{c}0.0329 \\
(0.1384)\end{array}$ & $\begin{array}{l}-0.0029 \\
(0.0805)\end{array}$ & $\begin{array}{c}4.4759 \\
(7.5804)\end{array}$ & $\begin{array}{l}-3.0220 \\
(6.2272)\end{array}$ \\
\hline 2+ EITC kids*1998 & $\begin{array}{c}0.2529 \\
(0.6084)\end{array}$ & $\begin{array}{l}-0.2311 \\
(0.3253)\end{array}$ & $\begin{array}{l}-0.2669 \\
(0.2413)\end{array}$ & $\begin{array}{l}-3.1981 \\
(5.4870)\end{array}$ & $\begin{array}{l}-4.9393 \\
(4.7732)\end{array}$ \\
\hline R-squared & 0.0807 & 0.0555 & 0.0948 & 0.1200 & 0.1016 \\
\hline
\end{tabular}

Robust standard errors in parentheses. All Models control for state fixed effects and year dummies. $* * * \mathbf{p}<0.01, * * \mathbf{p}<0.05$ Each cell represents a separate regression and each regression includes the full set of controls shown in Table 2 plus state fixed effects. Numbers of observations and numbers of IDs are the same as in Table 6. 
Table 9. DD + Mother FE by Race/Ethnicity and Maternal Marital Status with Pre-Policy Trends

\begin{tabular}{lcccc}
\hline VARIABLES & Illness & Accident & HOME & BPI \\
& & & & Z-Score \\
\hline White + Hispanic, Unmarried & & & & \\
\hline & & & & \\
2+ EITC kids*after & 0.1564 & -0.0505 & $7.6393 * * *$ & 0.5008 \\
& $(0.0902)$ & $(0.0572)$ & $(2.7687)$ & $(2.2169)$ \\
2+ EITC kids*1992 & 0.1313 & -0.0628 & 2.9945 & -1.0987 \\
& $(0.0891)$ & $(0.0646)$ & $(2.5025)$ & $(2.0483)$ \\
R-squared & 0.0685 & 0.0399 & 0.0530 & 0.0589 \\
\hline White + Hispanic, Married & & & & \\
\hline & & & & \\
2+ EITC kids*after & -0.0275 & $-0.1420 * *$ & 2.1482 & 2.6328 \\
& $(0.0854)$ & $(0.0582)$ & $(1.7316)$ & $(2.3256)$ \\
2+ EITC kids*1992 & -0.0157 & -0.0125 & -1.9142 & 1.2971 \\
R-squared & $(0.0898)$ & $(0.0527)$ & $(1.7161)$ & $(1.8532)$ \\
\hline Black, Unmarried & 0.0549 & 0.0309 & 0.0551 & 0.0572 \\
\hline 2+ EITC kids*after & & & & \\
2+ EITC kids*1992 & 0.0051 & -0.1447 & 4.7492 & -0.5795 \\
R-squared & $(0.1351)$ & $(0.0782)$ & $(2.9799)$ & $(3.6548)$ \\
\hline Black, Married & 0.1170 & -0.0749 & 2.1819 & 2.7439 \\
2+ EITC kids*after & $(0.1285)$ & $(0.0588)$ & $(3.4236)$ & $(2.7516)$ \\
2+ EITC kids*1992 & 0.0431 & 0.0360 & 0.0477 & 0.0506 \\
\hline R-squared & & & & \\
\hline
\end{tabular}

Robust standard errors in parentheses. All Models control for state fixed effects and year dummies. $* * * \mathbf{p}<0.01, * * p<0.05$ Each cell represents a separate regression and each regression includes the full set of controls shown in Table 2 plus state fixed effects. Numbers of observations and numbers of IDs are the same as in Table 6. Mother-rated health is not included because this question was only asked in years 1992, 1996, and 1998. 
Table 1. DD for White + Hispanic Unmarried Mothers

\begin{tabular}{|c|c|c|c|c|c|}
\hline VARIABLES & $\begin{array}{c}(1) \\
\text { Mother-Rated } \\
\text { Health } \\
\end{array}$ & $\begin{array}{c}(2) \\
\text { Illness }\end{array}$ & $\begin{array}{c}\text { (3) } \\
\text { Accident }\end{array}$ & $\begin{array}{c}\text { (4) } \\
\text { HOME } \\
\text { Z-Score } \\
\end{array}$ & $\begin{array}{c}\text { (5) } \\
\text { BPI } \\
\text { Z-Score } \\
\end{array}$ \\
\hline 2+ EITC kids*after & $\begin{array}{c}0.1237 \\
(0.2548)\end{array}$ & $\begin{array}{c}0.0403 \\
(0.0656)\end{array}$ & $\begin{array}{l}-0.0102 \\
(0.0404)\end{array}$ & $\begin{array}{c}4.5459 * * \\
(2.0295)\end{array}$ & $\begin{array}{c}1.1280 \\
(2.1266)\end{array}$ \\
\hline 2+ EITC kids & $\begin{array}{l}-0.2666 \\
(0.2661)\end{array}$ & $\begin{array}{l}-0.1067 \\
(0.0554)\end{array}$ & $\begin{array}{c}0.0457 \\
(0.0326)\end{array}$ & $\begin{array}{c}-6.3087^{* * *} \\
(1.8068)\end{array}$ & $\begin{array}{c}0.2383 \\
(2.3094)\end{array}$ \\
\hline Year $=1996$ or 1998 & $\begin{array}{c}0.1064 \\
(0.3173)\end{array}$ & $\begin{array}{l}-0.0558 \\
(0.1049)\end{array}$ & $\begin{array}{c}0.0444 \\
(0.0728)\end{array}$ & $\begin{array}{l}-6.1619 \\
(3.6543)\end{array}$ & $\begin{array}{l}-5.0517 \\
(3.8867)\end{array}$ \\
\hline Age of child, year & $\begin{array}{c}0.0037 \\
(0.0101)\end{array}$ & $\begin{array}{c}-0.0203 * * * \\
(0.0046)\end{array}$ & $\begin{array}{c}0.0034 \\
(0.0032)\end{array}$ & $\begin{array}{c}0.0397 \\
(0.1679)\end{array}$ & $\begin{array}{c}0.7427 * * * \\
(0.2326)\end{array}$ \\
\hline Mom's age & $\begin{array}{l}-0.0225 \\
(0.0138)\end{array}$ & $\begin{array}{c}0.0156 * * \\
(0.0071)\end{array}$ & $\begin{array}{c}0.0088 * * \\
(0.0044)\end{array}$ & $\begin{array}{c}0.3516 \\
(0.2631)\end{array}$ & $\begin{array}{l}-0.0533 \\
(0.3061)\end{array}$ \\
\hline \# EITC elig kids in HH & $\begin{array}{c}0.0348 \\
(0.0357)\end{array}$ & $\begin{array}{c}-0.0309 * * \\
(0.0120)\end{array}$ & $\begin{array}{c}-0.0252 * * * \\
(0.0074)\end{array}$ & $\begin{array}{l}-1.0259 \\
(0.5468)\end{array}$ & $\begin{array}{l}-0.8900 \\
(0.7644)\end{array}$ \\
\hline Mom's educ. years & $\begin{array}{c}0.0281 \\
(0.0196)\end{array}$ & $\begin{array}{c}0.0112 \\
(0.0079)\end{array}$ & $\begin{array}{c}0.0010 \\
(0.0054)\end{array}$ & $\begin{array}{c}1.2952 * * * \\
(0.3937)\end{array}$ & $\begin{array}{l}-0.7083 \\
(0.3855)\end{array}$ \\
\hline State AFDC ben. \$ & $\begin{array}{l}-0.5482 \\
(0.9023)\end{array}$ & $\begin{array}{c}0.8507 * * * \\
(0.2985)\end{array}$ & $\begin{array}{c}0.2770 \\
(0.2082)\end{array}$ & $\begin{array}{c}-2.8592 \\
(13.0703)\end{array}$ & $\begin{array}{c}0.3634 \\
(11.3912)\end{array}$ \\
\hline State unemp. rate & $\begin{array}{c}0.0311 \\
(0.0724)\end{array}$ & $\begin{array}{c}0.0325 \\
(0.0201)\end{array}$ & $\begin{array}{c}0.0224 \\
(0.0151)\end{array}$ & $\begin{array}{c}0.2706 \\
(0.8182)\end{array}$ & $\begin{array}{l}-0.3497 \\
(0.6912)\end{array}$ \\
\hline Medicaid elig. Cutoff \$ & $\begin{array}{l}-0.0028 \\
(0.0023)\end{array}$ & $\begin{array}{c}0.0009 \\
(0.0016)\end{array}$ & $\begin{array}{l}-0.0010 \\
(0.0007)\end{array}$ & $\begin{array}{c}0.0799 * * \\
(0.0400)\end{array}$ & $\begin{array}{c}0.0629 \\
(0.0568)\end{array}$ \\
\hline Constant & $\begin{array}{c}4.4606 * * * \\
(0.7780)\end{array}$ & $\begin{array}{l}-0.5743 \\
(0.3637)\end{array}$ & $\begin{array}{l}-0.2382 \\
(0.2266)\end{array}$ & $\begin{array}{c}62.5559 * * * \\
(12.1275)\end{array}$ & $\begin{array}{c}111.9553 * * * \\
(14.8504)\end{array}$ \\
\hline $\begin{array}{l}\text { Observations } \\
\text { R-squared }\end{array}$ & $\begin{array}{c}690 \\
0.1072\end{array}$ & $\begin{array}{c}1,553 \\
0.1338\end{array}$ & $\begin{array}{c}1,564 \\
0.0763\end{array}$ & $\begin{array}{c}1,492 \\
0.1674\end{array}$ & $\begin{array}{c}1,273 \\
0.1135\end{array}$ \\
\hline
\end{tabular}

Robust standard errors in parentheses. All Models include state fixed effects and year dummies. ${ }^{* * *} \mathbf{p}<0.01, * * \mathbf{p}<0.05$ 
Table 2. DD for White + Hispanic Married Mothers

\begin{tabular}{|c|c|c|c|c|c|}
\hline VARIABLES & $\begin{array}{c}\text { (1) } \\
\text { Mother-Rated } \\
\text { Health } \\
\end{array}$ & $\begin{array}{l}\text { (2) } \\
\text { Illness }\end{array}$ & $\begin{array}{c}\text { (3) } \\
\text { Accident }\end{array}$ & $\begin{array}{c}\text { (4) } \\
\text { HOME } \\
\text { Z-Score } \\
\end{array}$ & $\begin{array}{c}\text { (5) } \\
\text { BPI } \\
\text { Z-Score } \\
\end{array}$ \\
\hline 2+ EITC kids*after & $\begin{array}{c}0.6191 * * * \\
(0.1581)\end{array}$ & $\begin{array}{c}0.0167 \\
(0.0597)\end{array}$ & $\begin{array}{l}-0.0540 \\
(0.0400)\end{array}$ & $\begin{array}{c}4.3650 * * * \\
(1.4692)\end{array}$ & $\begin{array}{c}-3.9583 * * \\
(1.9551)\end{array}$ \\
\hline 2+ EITC kids & $\begin{array}{c}-0.5255^{* * *} \\
(0.1499)\end{array}$ & $\begin{array}{c}-0.0841 \\
(0.0475)\end{array}$ & $\begin{array}{c}0.0440 \\
(0.0260)\end{array}$ & $\begin{array}{c}-2.7500 * * \\
(1.3969)\end{array}$ & $\begin{array}{c}2.1063 \\
(1.9150)\end{array}$ \\
\hline Year $=1996$ or 1998 & $\begin{array}{l}-0.1885 \\
(0.1832)\end{array}$ & $\begin{array}{l}-0.0288 \\
(0.0828)\end{array}$ & $\begin{array}{c}0.0240 \\
(0.0506)\end{array}$ & $\begin{array}{c}-8.2676 * * * \\
(2.2033)\end{array}$ & $\begin{array}{c}3.9885 \\
(2.7452)\end{array}$ \\
\hline Age of child, year & $\begin{array}{c}-0.0174^{* * *} \\
(0.0053)\end{array}$ & $\begin{array}{c}-0.0220 * * * \\
(0.0033)\end{array}$ & $\begin{array}{c}0.0053 * * * \\
(0.0020)\end{array}$ & $\begin{array}{c}0.3721^{* * * *} \\
(0.1003)\end{array}$ & $\begin{array}{c}0.5510^{* * * *} \\
(0.1412)\end{array}$ \\
\hline Mom's age & $\begin{array}{c}0.0059 \\
(0.0083)\end{array}$ & $\begin{array}{l}-0.0013 \\
(0.0051)\end{array}$ & $\begin{array}{l}-0.0041 \\
(0.0025)\end{array}$ & $\begin{array}{c}0.5957 * * * \\
(0.1882)\end{array}$ & $\begin{array}{c}-0.3496 \\
(0.2173)\end{array}$ \\
\hline \# EITC elig kids in $\mathrm{HH}$ & $\begin{array}{l}-0.0035 \\
(0.0152)\end{array}$ & $\begin{array}{c}-0.0333 * * * \\
(0.0120)\end{array}$ & $\begin{array}{l}-0.0025 \\
(0.0049)\end{array}$ & $\begin{array}{c}-1.6147 * * * \\
(0.4117)\end{array}$ & $\begin{array}{c}0.1547 \\
(0.4621)\end{array}$ \\
\hline Mom's educ. years & $\begin{array}{c}0.0534 * * * \\
(0.0156)\end{array}$ & $\begin{array}{c}0.0168 * * * \\
(0.0060)\end{array}$ & $\begin{array}{c}0.0063 * * \\
(0.0031)\end{array}$ & $\begin{array}{c}1.5872 * * * \\
(0.2390)\end{array}$ & $\begin{array}{c}-0.9776 * * * \\
(0.3484)\end{array}$ \\
\hline State AFDC ben. \$ & $\begin{array}{l}-0.4776 \\
(0.5947)\end{array}$ & $\begin{array}{c}0.1107 \\
(0.2126)\end{array}$ & $\begin{array}{l}-0.1970 \\
(0.1262)\end{array}$ & $\begin{array}{c}4.4968 \\
(6.7342)\end{array}$ & $\begin{array}{l}-3.8247 \\
(7.3789)\end{array}$ \\
\hline State unemp. rate & $\begin{array}{c}0.0952 \\
(0.0504)\end{array}$ & $\begin{array}{c}0.0023 \\
(0.0146)\end{array}$ & $\begin{array}{l}-0.0108 \\
(0.0081)\end{array}$ & $\begin{array}{c}0.0894 \\
(0.4092)\end{array}$ & $\begin{array}{c}0.0748 \\
(0.4560)\end{array}$ \\
\hline Medicaid elig. Cutoff \$ & $\begin{array}{l}-0.0000 \\
(0.0013)\end{array}$ & $\begin{array}{l}-0.0003 \\
(0.0009)\end{array}$ & $\begin{array}{c}0.0013 \\
(0.0007)\end{array}$ & $\begin{array}{l}-0.0479 * \\
(0.0280)\end{array}$ & $\begin{array}{c}-0.1094 * * * \\
(0.0417)\end{array}$ \\
\hline Constant & $\begin{array}{c}3.1412 * * * \\
(0.5007)\end{array}$ & $\begin{array}{l}0.5039 * \\
(0.2614)\end{array}$ & $\begin{array}{c}0.0163 \\
(0.1552)\end{array}$ & $\begin{array}{c}74.9418 * * * \\
(8.8037)\end{array}$ & $\begin{array}{c}136.4672 * * * \\
(11.7620)\end{array}$ \\
\hline $\begin{array}{l}\text { Observations } \\
\text { R-squared }\end{array}$ & $\begin{array}{c}1,720 \\
0.0911\end{array}$ & $\begin{array}{c}3,812 \\
0.1033\end{array}$ & $\begin{array}{c}3,852 \\
0.0290\end{array}$ & $\begin{array}{c}3,656 \\
0.1813\end{array}$ & $\begin{array}{c}2,992 \\
0.0867\end{array}$ \\
\hline
\end{tabular}

Robust standard errors in parentheses. All Models include state fixed effects and year dummies. ${ }^{* * *} \mathbf{p}<0.01, * * \mathbf{p}<0.05$ 
Table 3. DD for Black Unmarried Mothers

\begin{tabular}{|c|c|c|c|c|c|}
\hline VARIABLES & $\begin{array}{c}\text { (1) } \\
\text { Mother-Rated } \\
\text { Health } \\
\end{array}$ & $\begin{array}{l}\text { (2) } \\
\text { Illness }\end{array}$ & $\begin{array}{c}\text { (3) } \\
\text { Accident }\end{array}$ & $\begin{array}{c}\text { (4) } \\
\text { HOME } \\
\text { Z-Score } \\
\end{array}$ & $\begin{array}{c}\text { (5) } \\
\text { BPI } \\
\text { Z-Score } \\
\end{array}$ \\
\hline 2+ EITC kids*after & $\begin{array}{c}0.4277^{* *} \\
(0.2018)\end{array}$ & $\begin{array}{c}-0.0642 \\
(0.0889)\end{array}$ & $\begin{array}{l}-0.0914 \\
(0.0721)\end{array}$ & $\begin{array}{c}2.5362 \\
(2.7128)\end{array}$ & $\begin{array}{c}1.6506 \\
(3.1389)\end{array}$ \\
\hline 2+ EITC kids & $\begin{array}{c}-0.4102^{* *} \\
(0.1915)\end{array}$ & $\begin{array}{c}0.0369 \\
(0.0660)\end{array}$ & $\begin{array}{c}0.0459 \\
(0.0323)\end{array}$ & $\begin{array}{l}-4.9460^{*} \\
(2.9622)\end{array}$ & $\begin{array}{l}-2.0174 \\
(3.2416)\end{array}$ \\
\hline Year $=1996$ or 1998 & $\begin{array}{l}-0.4472 \\
(0.3203)\end{array}$ & $\begin{array}{c}0.1292 \\
(0.1177)\end{array}$ & $\begin{array}{c}0.1131 \\
(0.0833)\end{array}$ & $\begin{array}{l}-7.0007 \\
(4.2990)\end{array}$ & $\begin{array}{l}-5.9879 \\
(4.9284)\end{array}$ \\
\hline Age of child, year & $\begin{array}{l}-0.0143 \\
(0.0106)\end{array}$ & $\begin{array}{c}-0.0153 * * * \\
(0.0036)\end{array}$ & $\begin{array}{c}0.0060 * * * \\
(0.0021)\end{array}$ & $\begin{array}{c}0.4907 * * * \\
(0.1723)\end{array}$ & $\begin{array}{c}0.7330 * * * \\
(0.2030)\end{array}$ \\
\hline Mom's age & $\begin{array}{c}0.0033 \\
(0.0145)\end{array}$ & $\begin{array}{l}-0.0080 \\
(0.0059)\end{array}$ & $\begin{array}{c}0.0009 \\
(0.0029)\end{array}$ & $\begin{array}{l}-0.1670 \\
(0.3410)\end{array}$ & $\begin{array}{l}-0.2464 \\
(0.3046)\end{array}$ \\
\hline \# EITC elig kids in HH & $\begin{array}{l}-0.0101 \\
(0.0270)\end{array}$ & $\begin{array}{c}-0.0310^{* * * *} \\
(0.0083)\end{array}$ & $\begin{array}{l}-0.0052 \\
(0.0044)\end{array}$ & $\begin{array}{c}-2.9461^{* * *} \\
(0.5191)\end{array}$ & $\begin{array}{l}-0.5634 \\
(0.7104)\end{array}$ \\
\hline Mom's educ. years & $\begin{array}{c}0.0730 * * \\
(0.0299)\end{array}$ & $\begin{array}{c}0.0078 \\
(0.0103)\end{array}$ & $\begin{array}{c}0.0058 \\
(0.0057)\end{array}$ & $\begin{array}{c}2.1462 * * * \\
(0.6605)\end{array}$ & $\begin{array}{c}-2.0525^{* * *} \\
(0.6619)\end{array}$ \\
\hline State AFDC ben. \$ & $\begin{array}{c}-0.8931 \\
(1.4513)\end{array}$ & $\begin{array}{c}0.6041 \\
(0.4468)\end{array}$ & $\begin{array}{c}0.2694 \\
(0.2587)\end{array}$ & $\begin{array}{c}2.2646 \\
(18.1841)\end{array}$ & $\begin{array}{c}-18.5756 \\
(17.1230)\end{array}$ \\
\hline State unemp. rate & $\begin{array}{l}-0.0198 \\
(0.0917)\end{array}$ & $\begin{array}{l}-0.0154 \\
(0.0211)\end{array}$ & $\begin{array}{c}0.0154 \\
(0.0118)\end{array}$ & $\begin{array}{l}-1.1623 \\
(0.8698)\end{array}$ & $\begin{array}{l}-0.8021 \\
(1.0271)\end{array}$ \\
\hline Medicaid elig. Cutoff \$ & $\begin{array}{l}-0.0009 \\
(0.0024)\end{array}$ & $\begin{array}{l}0.0016^{*} \\
(0.0010)\end{array}$ & $\begin{array}{c}0.0008 \\
(0.0007)\end{array}$ & $\begin{array}{c}0.0565 \\
(0.0774)\end{array}$ & $\begin{array}{l}-0.0046 \\
(0.0767)\end{array}$ \\
\hline Constant & $\begin{array}{c}3.5338 * * * \\
(1.0366)\end{array}$ & $\begin{array}{c}0.3265 \\
(0.3401)\end{array}$ & $\begin{array}{c}-0.3407 * \\
(0.1937)\end{array}$ & $\begin{array}{c}70.0630 * * * \\
(18.9497)\end{array}$ & $\begin{array}{c}141.7504 * * * \\
(18.3983)\end{array}$ \\
\hline $\begin{array}{l}\text { Observations } \\
\text { R-squared }\end{array}$ & $\begin{array}{c}747 \\
0.1175\end{array}$ & $\begin{array}{c}1,677 \\
0.0761\end{array}$ & $\begin{array}{c}1,693 \\
0.0425\end{array}$ & $\begin{array}{c}1,599 \\
0.1934\end{array}$ & $\begin{array}{c}1,293 \\
0.1272\end{array}$ \\
\hline
\end{tabular}

Robust standard errors in parentheses. All Models include state fixed effects and year dummies. $* * * \mathbf{p}<0.01, * * \mathbf{p}<0.05$ 
Table 4. DD for Black Married Mothers

\begin{tabular}{|c|c|c|c|c|c|}
\hline VARIABLES & $\begin{array}{c}(1) \\
\text { Mother-Rated } \\
\text { Health } \\
\end{array}$ & $\begin{array}{l}\text { (2) } \\
\text { Illness }\end{array}$ & $\begin{array}{c}\text { (3) } \\
\text { Accident }\end{array}$ & $\begin{array}{c}\text { (4) } \\
\text { HOME } \\
\text { Z-Score } \\
\end{array}$ & $\begin{array}{c}\text { (5) } \\
\text { BPI } \\
\text { Z-Score } \\
\end{array}$ \\
\hline 2+ EITC kids*after & $\begin{array}{l}-0.0734 \\
(0.4038)\end{array}$ & $\begin{array}{l}-0.226{ }^{*} \\
(0.1188)\end{array}$ & $\begin{array}{l}-0.0052 \\
(0.1146)\end{array}$ & $\begin{array}{c}8.7744 \\
(5.3915)\end{array}$ & $\begin{array}{l}-7.1026 \\
(4.5377)\end{array}$ \\
\hline 2+ EITC kids & $\begin{array}{l}-0.0898 \\
(0.4367)\end{array}$ & $\begin{array}{c}0.0865 \\
(0.1133)\end{array}$ & $\begin{array}{l}-0.0408 \\
(0.0962)\end{array}$ & $\begin{array}{l}-9.2897 * \\
(4.9846)\end{array}$ & $\begin{array}{c}3.3037 \\
(5.2871)\end{array}$ \\
\hline Year $=1996$ or 1998 & $\begin{array}{c}0.0199 \\
(0.1194)\end{array}$ & $\begin{array}{c}0.1789 \\
(0.1706)\end{array}$ & $\begin{array}{c}0.0205 \\
(0.1339)\end{array}$ & $\begin{array}{l}-7.4114 \\
(7.4635)\end{array}$ & $\begin{array}{l}11.4950^{*} \\
(6.8385)\end{array}$ \\
\hline Age of child, year & $\begin{array}{l}-0.0047 \\
(0.0128)\end{array}$ & $\begin{array}{c}-0.0222 * * * \\
(0.0066)\end{array}$ & $\begin{array}{c}0.0037 \\
(0.0041)\end{array}$ & $\begin{array}{c}0.8360 * * * \\
(0.2541)\end{array}$ & $\begin{array}{l}0.4209 * \\
(0.2491)\end{array}$ \\
\hline Mom's age & $\begin{array}{c}0.0133 \\
(0.0188)\end{array}$ & $\begin{array}{c}0.0069 \\
(0.0098)\end{array}$ & $\begin{array}{l}-0.0062 \\
(0.0049)\end{array}$ & $\begin{array}{c}0.1647 \\
(0.4486)\end{array}$ & $\begin{array}{c}0.1791 \\
(0.4033)\end{array}$ \\
\hline \# EITC elig kids in $\mathrm{HH}$ & $\begin{array}{l}0.0690 * \\
(0.0391)\end{array}$ & $\begin{array}{l}-0.0004 \\
(0.0342)\end{array}$ & $\begin{array}{c}0.0129 \\
(0.0123)\end{array}$ & $\begin{array}{c}0.3864 \\
(0.9434)\end{array}$ & $\begin{array}{l}-0.6773 \\
(0.6796)\end{array}$ \\
\hline Mom's educ. years & $\begin{array}{c}0.0528 \\
(0.0552)\end{array}$ & $\begin{array}{l}-0.0175 \\
(0.0230)\end{array}$ & $\begin{array}{c}0.0133 \\
(0.0105)\end{array}$ & $\begin{array}{l}3.0816^{* *} \\
(1.3324)\end{array}$ & $\begin{array}{l}-1.4298 \\
(1.1482)\end{array}$ \\
\hline State AFDC ben. \$ & $\begin{array}{c}0.0009 \\
(4.3086)\end{array}$ & $\begin{array}{c}0.4357 \\
(0.7100)\end{array}$ & $\begin{array}{c}0.1344 \\
(0.4428)\end{array}$ & $\begin{array}{c}18.8244 \\
(21.0618)\end{array}$ & $\begin{array}{c}44.2856 \\
(31.5409)\end{array}$ \\
\hline State unemp. rate & $\begin{array}{l}-0.0323 \\
(0.0910)\end{array}$ & $\begin{array}{l}-0.0120 \\
(0.0284)\end{array}$ & $\begin{array}{c}0.0238 \\
(0.0204)\end{array}$ & $\begin{array}{c}1.6898 \\
(1.2483)\end{array}$ & $\begin{array}{c}1.4855 \\
(1.3448)\end{array}$ \\
\hline Medicaid elig. Cutoff \$ & $\begin{array}{c}0.0022 \\
(0.0022)\end{array}$ & $\begin{array}{c}0.0001 \\
(0.0012)\end{array}$ & $\begin{array}{l}-0.0014 \\
(0.0009)\end{array}$ & $\begin{array}{c}0.0570 \\
(0.0522)\end{array}$ & $\begin{array}{c}0.1042 \\
(0.0695)\end{array}$ \\
\hline Constant & $\begin{array}{c}2.5452 * * \\
(1.1719)\end{array}$ & $\begin{array}{c}0.0725 \\
(0.4732)\end{array}$ & $\begin{array}{c}0.0696 \\
(0.3311)\end{array}$ & $\begin{array}{c}36.0271 \\
(24.7617)\end{array}$ & $\begin{array}{c}83.8339 * * * \\
(23.4730)\end{array}$ \\
\hline $\begin{array}{l}\text { Observations } \\
\text { R-squared }\end{array}$ & $\begin{array}{c}352 \\
0.1422 \\
\end{array}$ & $\begin{array}{c}858 \\
0.0999 \\
\end{array}$ & $\begin{array}{c}866 \\
0.0599\end{array}$ & $\begin{array}{c}816 \\
0.1374\end{array}$ & $\begin{array}{c}648 \\
0.1677\end{array}$ \\
\hline
\end{tabular}

Robust standard errors in parentheses. All Models include state fixed effects and year dummies. ${ }^{* * *} \mathbf{p}<0.01, * * \mathbf{p}<0.05$ 
Table 5. DD + Mother FE for White + Hispanic Unmarried Mothers

\begin{tabular}{|c|c|c|c|c|c|}
\hline VARIABLES & $\begin{array}{c}\text { (1) } \\
\text { Mother-Rated } \\
\text { Health } \\
\end{array}$ & $\begin{array}{l}\text { (2) } \\
\text { Illness }\end{array}$ & $\begin{array}{c}\text { (3) } \\
\text { Accident }\end{array}$ & $\begin{array}{c}\text { (4) } \\
\text { HOME } \\
\text { Z-Score } \\
\end{array}$ & $\begin{array}{c}\text { (5) } \\
\text { BPI } \\
\text { Z-Score } \\
\end{array}$ \\
\hline 2+ EITC kids*after & $\begin{array}{c}-0.1913 \\
(0.2888)\end{array}$ & $\begin{array}{c}0.0778 \\
(0.0729)\end{array}$ & $\begin{array}{c}-0.0130 \\
(0.0405)\end{array}$ & $\begin{array}{c}5.7593^{* *} \\
(2.3054)\end{array}$ & $\begin{array}{c}1.1535 \\
(2.1070)\end{array}$ \\
\hline Year $=1996$ or 1998 & $\begin{array}{c}1.1817 \\
(0.7872)\end{array}$ & $\begin{array}{c}-0.3482 \\
(0.3546)\end{array}$ & $\begin{array}{c}-0.2019 \\
(0.2752)\end{array}$ & $\begin{array}{c}-3.3471 \\
(13.3791)\end{array}$ & $\begin{array}{l}-6.7428 \\
(9.5602)\end{array}$ \\
\hline Age of child, year & $\begin{array}{c}-0.0140 \\
(0.0091)\end{array}$ & $\begin{array}{l}-0.0103 \\
(0.0059)\end{array}$ & $\begin{array}{c}0.0043 \\
(0.0052)\end{array}$ & $\begin{array}{c}0.4848 * * * \\
(0.1404)\end{array}$ & $\begin{array}{c}1.1334 * * * \\
(0.3009)\end{array}$ \\
\hline Mom's age & $\begin{array}{l}-0.1317 \\
(0.1315)\end{array}$ & $\begin{array}{c}0.0416 \\
(0.0585)\end{array}$ & $\begin{array}{c}0.0624 \\
(0.0463)\end{array}$ & $\begin{array}{l}-1.2875 \\
(2.2462)\end{array}$ & $\begin{array}{c}0.4064 \\
(1.5797)\end{array}$ \\
\hline \# EITC elig kids in $\mathrm{HH}$ & $\begin{array}{c}0.0857 \\
(0.1189)\end{array}$ & $\begin{array}{c}0.0085 \\
(0.0257)\end{array}$ & $\begin{array}{l}-0.0456 \\
(0.0263)\end{array}$ & $\begin{array}{c}-0.9390 \\
(1.7474)\end{array}$ & $\begin{array}{c}-0.7351 \\
(1.6255)\end{array}$ \\
\hline Mom's educ. years & $\begin{array}{c}-0.1781 \\
(0.0920)\end{array}$ & $\begin{array}{c}-0.0592 \\
(0.0331)\end{array}$ & $\begin{array}{c}-0.0671^{* *} \\
(0.0337)\end{array}$ & $\begin{array}{l}-1.0911 \\
(1.3486)\end{array}$ & $\begin{array}{c}1.4768 \\
(1.9308)\end{array}$ \\
\hline State AFDC ben. \$ & $\begin{array}{l}-1.2832 \\
(1.2133)\end{array}$ & $\begin{array}{c}0.4521 \\
(0.3067)\end{array}$ & $\begin{array}{c}0.3903 \\
(0.2563)\end{array}$ & $\begin{array}{l}-12.6240 \\
(14.8956)\end{array}$ & $\begin{array}{c}5.8460 \\
(11.4730)\end{array}$ \\
\hline State unemp. rate & $\begin{array}{c}0.0372 \\
(0.0920)\end{array}$ & $\begin{array}{c}0.0140 \\
(0.0221)\end{array}$ & $\begin{array}{c}0.0305 \\
(0.0175)\end{array}$ & $\begin{array}{l}-0.6267 \\
(0.7121)\end{array}$ & $\begin{array}{c}0.1555 \\
(0.7405)\end{array}$ \\
\hline Medicaid elig. Cutoff \$ & $\begin{array}{c}0.0001 \\
(0.0039)\end{array}$ & $\begin{array}{c}-0.0003 \\
(0.0019)\end{array}$ & $\begin{array}{c}-0.0003 \\
(0.0016)\end{array}$ & $\begin{array}{c}0.0624 \\
(0.0607)\end{array}$ & $\begin{array}{c}0.0424 \\
(0.0493)\end{array}$ \\
\hline Constant & $\begin{array}{c}9.8557 * * \\
(4.6168)\end{array}$ & $\begin{array}{c}-0.3933 \\
(1.9783)\end{array}$ & $\begin{array}{l}-1.1979 \\
(1.5535)\end{array}$ & $\begin{array}{l}143.1281 \\
(74.5477)\end{array}$ & $\begin{array}{c}58.6298 \\
(59.0705)\end{array}$ \\
\hline $\begin{array}{l}\text { Observations } \\
\text { R-squared } \\
\text { Number of ID }\end{array}$ & $\begin{array}{c}690 \\
0.0595 \\
302\end{array}$ & $\begin{array}{c}1,553 \\
0.0663 \\
424\end{array}$ & $\begin{array}{c}1,564 \\
0.0391 \\
424\end{array}$ & $\begin{array}{c}1,492 \\
0.0517 \\
420\end{array}$ & $\begin{array}{c}1,273 \\
0.0587 \\
407\end{array}$ \\
\hline
\end{tabular}

Robust standard errors in parentheses. All Models include state fixed effects and year dummies. ${ }^{* * *} \mathbf{p}<0.01, * * \mathbf{p}<0.05$ 
Table 6. DD + Mother FE for White + Hispanic Married Mothers

\begin{tabular}{|c|c|c|c|c|c|}
\hline VARIABLES & $\begin{array}{c}(1) \\
\text { Mother-Rated } \\
\text { Health } \\
\end{array}$ & $\begin{array}{l}\text { (2) } \\
\text { Illness }\end{array}$ & $\begin{array}{c}\text { (3) } \\
\text { Accident }\end{array}$ & $\begin{array}{c}\text { (4) } \\
\text { HOME } \\
\text { Z-Score } \\
\end{array}$ & $\begin{array}{c}\text { (5) } \\
\text { BPI } \\
\text { Z-Score } \\
\end{array}$ \\
\hline 2+ EITC kids*after & $\begin{array}{c}1.1901 * * * \\
(0.0980)\end{array}$ & $\begin{array}{l}-0.0177 \\
(0.0688)\end{array}$ & $\begin{array}{c}-0.1342 * * * \\
(0.0439)\end{array}$ & $\begin{array}{c}3.3210 * * \\
(1.5233)\end{array}$ & $\begin{array}{c}1.7261 \\
(1.7847)\end{array}$ \\
\hline Year=1996 or 1998 & $\begin{array}{l}-0.2943 \\
(0.2805)\end{array}$ & $\begin{array}{l}-0.0363 \\
(0.2192)\end{array}$ & $\begin{array}{c}0.2635 \\
(0.1569)\end{array}$ & $\begin{array}{c}-16.1555^{* * *} \\
(5.8343)\end{array}$ & $\begin{array}{c}-12.9659 * * \\
(5.8377)\end{array}$ \\
\hline Age of child, year & $\begin{array}{l}-0.0033 \\
(0.0063)\end{array}$ & $\begin{array}{c}-0.0201 * * * \\
(0.0040)\end{array}$ & $\begin{array}{c}0.0047 \\
(0.0029)\end{array}$ & $\begin{array}{c}0.6994 * * * \\
(0.0896)\end{array}$ & $\begin{array}{c}0.7701^{* * *} \\
(0.1365)\end{array}$ \\
\hline Mom's age & $\begin{array}{l}-0.0513 \\
(0.0516)\end{array}$ & $\begin{array}{c}0.0161 \\
(0.0353)\end{array}$ & $\begin{array}{l}-0.0276 \\
(0.0256)\end{array}$ & $\begin{array}{c}1.6780 \\
(0.9510)\end{array}$ & $\begin{array}{c}1.2766 \\
(0.9548)\end{array}$ \\
\hline \# EITC elig kids in HH & $\begin{array}{l}-0.0596 \\
(0.0652)\end{array}$ & $\begin{array}{c}-0.0388 * * \\
(0.0186)\end{array}$ & $\begin{array}{l}-0.0123 \\
(0.0128)\end{array}$ & $\begin{array}{c}0.3015 \\
(0.7097)\end{array}$ & $\begin{array}{l}-0.6668 \\
(0.9811)\end{array}$ \\
\hline Mom's educ. years & $\begin{array}{l}-0.0101 \\
(0.0535)\end{array}$ & $\begin{array}{l}-0.0097 \\
(0.0356)\end{array}$ & $\begin{array}{l}-0.0089 \\
(0.0195)\end{array}$ & $\begin{array}{c}0.3024 \\
(0.6590)\end{array}$ & $\begin{array}{c}1.2512 \\
(1.2223)\end{array}$ \\
\hline State AFDC ben. \$ & $\begin{array}{l}-0.6336 \\
(0.6014)\end{array}$ & $\begin{array}{c}0.1489 \\
(0.2252)\end{array}$ & $\begin{array}{l}-0.1124 \\
(0.1378)\end{array}$ & $\begin{array}{l}-0.0293 \\
(6.5262)\end{array}$ & $\begin{array}{l}-0.0814 \\
(6.1604)\end{array}$ \\
\hline State unemp. rate & $\begin{array}{c}0.1696 * * * \\
(0.0574)\end{array}$ & $\begin{array}{c}0.0187 \\
(0.0156)\end{array}$ & $\begin{array}{l}-0.0097 \\
(0.0089)\end{array}$ & $\begin{array}{l}-0.0860 \\
(0.4157)\end{array}$ & $\begin{array}{l}-0.1245 \\
(0.4335)\end{array}$ \\
\hline Medicaid elig. Cutoff \$ & $\begin{array}{c}0.0012 \\
(0.0024)\end{array}$ & $\begin{array}{l}-0.0010 \\
(0.0015)\end{array}$ & $\begin{array}{c}0.0027 \\
(0.0016)\end{array}$ & $\begin{array}{l}-0.0586 \\
(0.0407)\end{array}$ & $\begin{array}{l}-0.0847 \\
(0.0486)\end{array}$ \\
\hline Constant & $\begin{array}{l}4.4829 * * \\
(1.9352)\end{array}$ & $\begin{array}{c}0.2880 \\
(1.2171)\end{array}$ & $\begin{array}{c}1.4159 \\
(0.8999)\end{array}$ & $\begin{array}{c}55.8964 \\
(31.5888)\end{array}$ & $\begin{array}{l}74.4444^{* *} \\
(34.0638)\end{array}$ \\
\hline $\begin{array}{l}\text { Observations } \\
\text { R-squared } \\
\text { Number of ID }\end{array}$ & $\begin{array}{c}1,720 \\
0.0402 \\
638\end{array}$ & $\begin{array}{c}3,812 \\
0.0549 \\
780\end{array}$ & $\begin{array}{c}3,852 \\
0.0309 \\
781\end{array}$ & $\begin{array}{c}3,656 \\
0.0547 \\
770\end{array}$ & $\begin{array}{c}2,992 \\
0.0571 \\
744\end{array}$ \\
\hline
\end{tabular}

Robust standard errors in parentheses. All Models include state fixed effects and year dummies. ${ }^{* * *} \mathbf{p}<0.01, * * p<0.05$ 
Table 7. DD + Mother FE for Black Unmarried Mothers

\begin{tabular}{|c|c|c|c|c|c|}
\hline VARIABLES & $\begin{array}{c}(1) \\
\text { Mother-Rated } \\
\text { Health } \\
\end{array}$ & $\begin{array}{c}\text { (2) } \\
\text { Illness }\end{array}$ & $\begin{array}{c}\text { (3) } \\
\text { Accident }\end{array}$ & $\begin{array}{c}\text { (4) } \\
\text { HOME } \\
\text { Z-Score } \\
\end{array}$ & $\begin{array}{c}\text { (5) } \\
\text { BPI } \\
\text { Z-Score } \\
\end{array}$ \\
\hline 2+ EITC kids*after & $\begin{array}{c}0.6320 * * \\
(0.3042)\end{array}$ & $\begin{array}{c}-0.0704 \\
(0.1025)\end{array}$ & $\begin{array}{c}-0.0964 \\
(0.0863)\end{array}$ & $\begin{array}{c}3.3524 \\
(2.5787)\end{array}$ & $\begin{array}{c}-2.1230 \\
(2.7601)\end{array}$ \\
\hline Year $=1996$ or 1998 & $\begin{array}{c}0.0194 \\
(0.9220)\end{array}$ & $\begin{array}{c}0.2062 \\
(0.3260)\end{array}$ & $\begin{array}{c}-0.0160 \\
(0.2014)\end{array}$ & $\begin{array}{c}1.0358 \\
(12.3716)\end{array}$ & $\begin{array}{c}-2.0774 \\
(12.8636)\end{array}$ \\
\hline Age of child, year & $\begin{array}{c}-0.0071 \\
(0.0136)\end{array}$ & $\begin{array}{c}-0.0149 * * * \\
(0.0043)\end{array}$ & $\begin{array}{c}0.0047 \\
(0.0030)\end{array}$ & $\begin{array}{c}0.8964 * * * \\
(0.1673)\end{array}$ & $\begin{array}{c}0.9114 * * * \\
(0.2071)\end{array}$ \\
\hline Mom's age & $\begin{array}{c}-0.0785 \\
(0.1405)\end{array}$ & $\begin{array}{c}-0.0230 \\
(0.0502)\end{array}$ & $\begin{array}{c}0.0265 \\
(0.0321)\end{array}$ & $\begin{array}{c}-1.9822 \\
(2.0478)\end{array}$ & $\begin{array}{c}-0.6799 \\
(1.9495)\end{array}$ \\
\hline \# EITC elig kids in $\mathbf{H H}$ & $\begin{array}{l}-0.0847 \\
(0.0695)\end{array}$ & $\begin{array}{c}-0.0592 * * * \\
(0.0220)\end{array}$ & $\begin{array}{l}-0.0205^{*} \\
(0.0121)\end{array}$ & $\begin{array}{c}-0.6833 \\
(1.1679)\end{array}$ & $\begin{array}{c}0.1293 \\
(0.9028)\end{array}$ \\
\hline Mom's educ. years & $\begin{array}{c}0.0611 \\
(0.1167)\end{array}$ & $\begin{array}{c}-0.0528 \\
(0.0608)\end{array}$ & $\begin{array}{c}-0.0156 \\
(0.0245)\end{array}$ & $\begin{array}{c}2.7510 \\
(3.9160)\end{array}$ & $\begin{array}{c}0.4678 \\
(3.8971)\end{array}$ \\
\hline State AFDC ben. \$ & $\begin{array}{c}1.0901 \\
(1.6873)\end{array}$ & $\begin{array}{c}0.6598 \\
(0.5053)\end{array}$ & $\begin{array}{c}0.3195 \\
(0.2459)\end{array}$ & $\begin{array}{c}2.6408 \\
(18.1314)\end{array}$ & $\begin{array}{c}-3.3689 \\
(18.6608)\end{array}$ \\
\hline State unemp. rate & $\begin{array}{c}0.0314 \\
(0.0881)\end{array}$ & $\begin{array}{c}-0.0225 \\
(0.0228)\end{array}$ & $\begin{array}{c}0.0190 \\
(0.0120)\end{array}$ & $\begin{array}{l}-1.5431^{*} \\
(0.9323)\end{array}$ & $\begin{array}{c}-0.6407 \\
(1.0464)\end{array}$ \\
\hline Medicaid elig. Cutoff \$ & $\begin{array}{c}0.0050 \\
(0.0085)\end{array}$ & $\begin{array}{c}0.0034 \\
(0.0024)\end{array}$ & $\begin{array}{l}0.0024 * \\
(0.0013)\end{array}$ & $\begin{array}{c}0.1453 \\
(0.0941)\end{array}$ & $\begin{array}{c}0.0471 \\
(0.0714)\end{array}$ \\
\hline Constant & $\begin{array}{c}4.4861 \\
(4.2124)\end{array}$ & $\begin{array}{c}0.9340 \\
(1.8549)\end{array}$ & $\begin{array}{l}-1.1958 \\
(1.0832)\end{array}$ & $\begin{array}{l}106.7298 \\
(75.7263)\end{array}$ & $\begin{array}{l}110.4437 \\
(69.7877)\end{array}$ \\
\hline $\begin{array}{l}\text { Observations } \\
\text { R-squared } \\
\text { Number of ID }\end{array}$ & $\begin{array}{c}747 \\
0.0162 \\
268\end{array}$ & $\begin{array}{c}1,677 \\
0.0423 \\
319\end{array}$ & $\begin{array}{c}1,693 \\
0.0353 \\
319\end{array}$ & $\begin{array}{c}1,599 \\
0.0475 \\
319\end{array}$ & $\begin{array}{c}1,293 \\
0.0503 \\
312\end{array}$ \\
\hline
\end{tabular}

Robust standard errors in parentheses. All Models include state fixed effects and year dummies. $* * * \mathbf{p}<0.01, * * \mathbf{p}<0.05$ 
Table 8. DD + Mother FE for Black + Hispanic Married Mothers

\begin{tabular}{|c|c|c|c|c|c|}
\hline VARIABLES & $\begin{array}{c}\text { (1) } \\
\text { Mother-Rated } \\
\text { Health } \\
\end{array}$ & $\begin{array}{c}\text { (2) } \\
\text { Illness }\end{array}$ & $\begin{array}{c}\text { (3) } \\
\text { Accident }\end{array}$ & $\begin{array}{c}\text { (4) } \\
\text { HOME } \\
\text { Z-Score } \\
\end{array}$ & $\begin{array}{c}\text { (5) } \\
\text { BPI } \\
\text { Z-Score } \\
\end{array}$ \\
\hline 2+ EITC kids*after & $\begin{array}{c}0.2673 \\
(0.6088)\end{array}$ & $\begin{array}{c}-0.0385 \\
(0.1595)\end{array}$ & $\begin{array}{c}-0.0743 \\
(0.1296)\end{array}$ & $\begin{array}{c}2.4016 \\
(7.1041)\end{array}$ & $\begin{array}{c}-3.6938 \\
(4.9184)\end{array}$ \\
\hline Year=1996 or 1998 & $\begin{array}{c}0.2673 \\
(0.6088)\end{array}$ & $\begin{array}{c}-0.3263 \\
(0.3865)\end{array}$ & $\begin{array}{c}0.1519 \\
(0.2301)\end{array}$ & $\begin{array}{c}-8.2038 \\
(12.9072)\end{array}$ & $\begin{array}{c}1.0035 \\
(15.2022)\end{array}$ \\
\hline Age of child, year & $\begin{array}{c}-0.0114 \\
(0.0127)\end{array}$ & $\begin{array}{c}-0.0151 \\
(0.0099)\end{array}$ & $\begin{array}{c}-0.0012 \\
(0.0058)\end{array}$ & $\begin{array}{c}1.0351 * * * \\
(0.2347)\end{array}$ & $\begin{array}{c}0.2333 \\
(0.2949)\end{array}$ \\
\hline Mom's age & $\begin{array}{l}-0.1455 \\
(0.1145)\end{array}$ & $\begin{array}{c}0.0549 \\
(0.0604)\end{array}$ & $\begin{array}{c}0.0122 \\
(0.0364)\end{array}$ & $\begin{array}{c}1.7073 \\
(1.8070)\end{array}$ & $\begin{array}{c}0.0308 \\
(2.3441)\end{array}$ \\
\hline \# EITC elig kids in HH & $\begin{array}{c}-0.1345 \\
(0.1136)\end{array}$ & $\begin{array}{c}-0.0133 \\
(0.0480)\end{array}$ & $\begin{array}{c}0.0031 \\
(0.0288)\end{array}$ & $\begin{array}{c}-3.3176 \\
(2.0150)\end{array}$ & $\begin{array}{l}2.3428 * \\
(1.2566)\end{array}$ \\
\hline Mom's educ. years & $\begin{array}{c}0.2244 \\
(0.1412)\end{array}$ & $\begin{array}{c}0.0853 \\
(0.0724)\end{array}$ & $\begin{array}{c}0.0972 \\
(0.0734)\end{array}$ & $\begin{array}{c}3.5661 \\
(2.5157)\end{array}$ & $\begin{array}{c}4.5468 \\
(3.4943)\end{array}$ \\
\hline State AFDC ben. \$ & $\begin{array}{c}2.6585 \\
(4.4538)\end{array}$ & $\begin{array}{c}1.0378 \\
(0.6311)\end{array}$ & $\begin{array}{c}0.3732 \\
(0.4076)\end{array}$ & $\begin{array}{c}5.6969 \\
(15.8033)\end{array}$ & $\begin{array}{c}12.2282 \\
(31.2350)\end{array}$ \\
\hline State unemp. rate & $\begin{array}{c}-0.1987 * * \\
(0.0900)\end{array}$ & $\begin{array}{c}-0.0259 \\
(0.0308)\end{array}$ & $\begin{array}{c}0.0658 * * * \\
(0.0207)\end{array}$ & $\begin{array}{l}2.0233^{*} \\
(1.1473)\end{array}$ & $\begin{array}{c}-0.4337 \\
(1.3011)\end{array}$ \\
\hline Medicaid elig. Cutoff \$ & $\begin{array}{c}-0.0003 \\
(0.0019)\end{array}$ & $\begin{array}{c}-0.0003 \\
(0.0013)\end{array}$ & $\begin{array}{c}0.0012 \\
(0.0009)\end{array}$ & $\begin{array}{c}0.3649 * * * \\
(0.0400)\end{array}$ & $\begin{array}{c}-0.2120 * * * \\
(0.0427)\end{array}$ \\
\hline Constant & $\begin{array}{c}6.7048 \\
(4.3084)\end{array}$ & $\begin{array}{c}-2.0846 \\
(2.2265)\end{array}$ & $\begin{array}{l}-2.3645 \\
(1.4585)\end{array}$ & $\begin{array}{l}-67.5464 \\
(63.4907)\end{array}$ & $\begin{array}{c}79.8573 \\
(72.6525)\end{array}$ \\
\hline $\begin{array}{l}\text { Observations } \\
\text { R-squared } \\
\text { Number of ID }\end{array}$ & $\begin{array}{c}352 \\
0.0785 \\
133\end{array}$ & $\begin{array}{c}858 \\
0.0537 \\
196\end{array}$ & $\begin{array}{c}866 \\
0.0908 \\
197\end{array}$ & $\begin{array}{c}816 \\
0.1181 \\
194\end{array}$ & $\begin{array}{c}648 \\
0.1014 \\
182\end{array}$ \\
\hline
\end{tabular}

Robust standard errors in parentheses. All Models include state fixed effects and year dummies. ${ }^{* * *} \mathbf{p}<0.01, * * \mathbf{p}<0.05$ 